\title{
Effects of local and global change on an inland sea: the Strait of Georgia, British Columbiar, Canada
}

\author{
S. C. Johannessen*, R. W. Macdonald \\ Department of Fisheries and Oceans, Institute of Ocean Sciences, 9860 West Saanich Road, Sidney, British Columbia V8L 4B2, \\ Canada
}

\begin{abstract}
Global changes manifest themselves in coastal waters depending on local oceanography and ecosystems. In this paper, we consider the Strait of Georgia as a case study. After examining physical and chemical processes and trends, we discuss consequences of change on geochemical cycling and biota. Several components of the system are vulnerable. Declines in $\mathrm{pH}$ and $\mathrm{O}_{2}$ of basin waters, partly imported from the shelf and partly supported by carbon cycling within the strait, could reduce benthic and pelagic habitat. Sea level rise and storms will interact with coastal development to place critical habitat, such as low-lying estuaries, intertidal zones and mudflats, at risk. The decrease and earlier peak in zooplankton biomass may lead to changes in the food web that cascade to higher trophic levels such as fish and birds. Anadromous fish, already showing declines, are vulnerable to ocean regime shifts, increasing river temperatures, habitat destruction, harvesting and contaminants. For southern resident killer whales Orcinus orca, a species at risk, decline in Chinook salmon Oncorhynchus tshawytscha together with marine traffic and biomagnifying contaminants will lead to extirpation if no action is taken. Some stressors can be controlled only through international action to mitigate climate change. However, we have local control of fishing, habitat destruction, release of some contaminants and, to some extent, river flow and temperature. Acting to control these stressors will support resilience of biota in the face of inevitable global changes.
\end{abstract}

KEY WORDS: Climate change - Strait of Georgia - Temperature - Anoxia $\cdot$ Coastal development · $\mathrm{pH} \cdot$ Fish $\cdot$ Marine mammals

\section{INTRODUCTION}

Coastal regions are likely to experience dramatic change in coming decades as a consequence of global climate change and local pressures from fishing, transport, habitat destruction and waste disposal. The global average surface air temperature has increased by $0.74^{\circ} \mathrm{C}$ (IPCC 2007b) over the past century and is projected to rise another 1.1 to $6.4^{\circ} \mathrm{C}$ by 2100 (IPCC $2007 \mathrm{~b}$ ). Sea level is also projected to rise by 0.2 to $0.6 \mathrm{~m}$ or more by 2100 (Hansen et al. 2007, IPCC 2007b), variability in climate is expected to increase, and the $\mathrm{pH}$ of the upper ocean will decrease (Doney et al. 2009).

Humans also affect ecosystems directly through fishing (Myers \& Worm 2003), contamination, and alter- ation of the hydrological cycle through damming, which together offer nothing less than transformative change (Jackson 2008). Global change will manifest itself regionally depending on site-specific characteristics of the marine environment. To identify vulnerability and to respond appropriately to change, it will be crucial to project change to regional and local scales where appropriate action may be taken.

In the present study, we examine the sensitivity to change of the Strait of Georgia, one of Canada's most important coastal seas (Fig. 1). Previous reviews have considered physical, biological and geochemical aspects of the strait (e.g. Thomson 1981, Harrison et al. 1983, Burd et al. 2008b, Hill et al. 2008). We do not attempt to provide another review of the characteristics of the Strait of Georgia. Rather, we examine the 

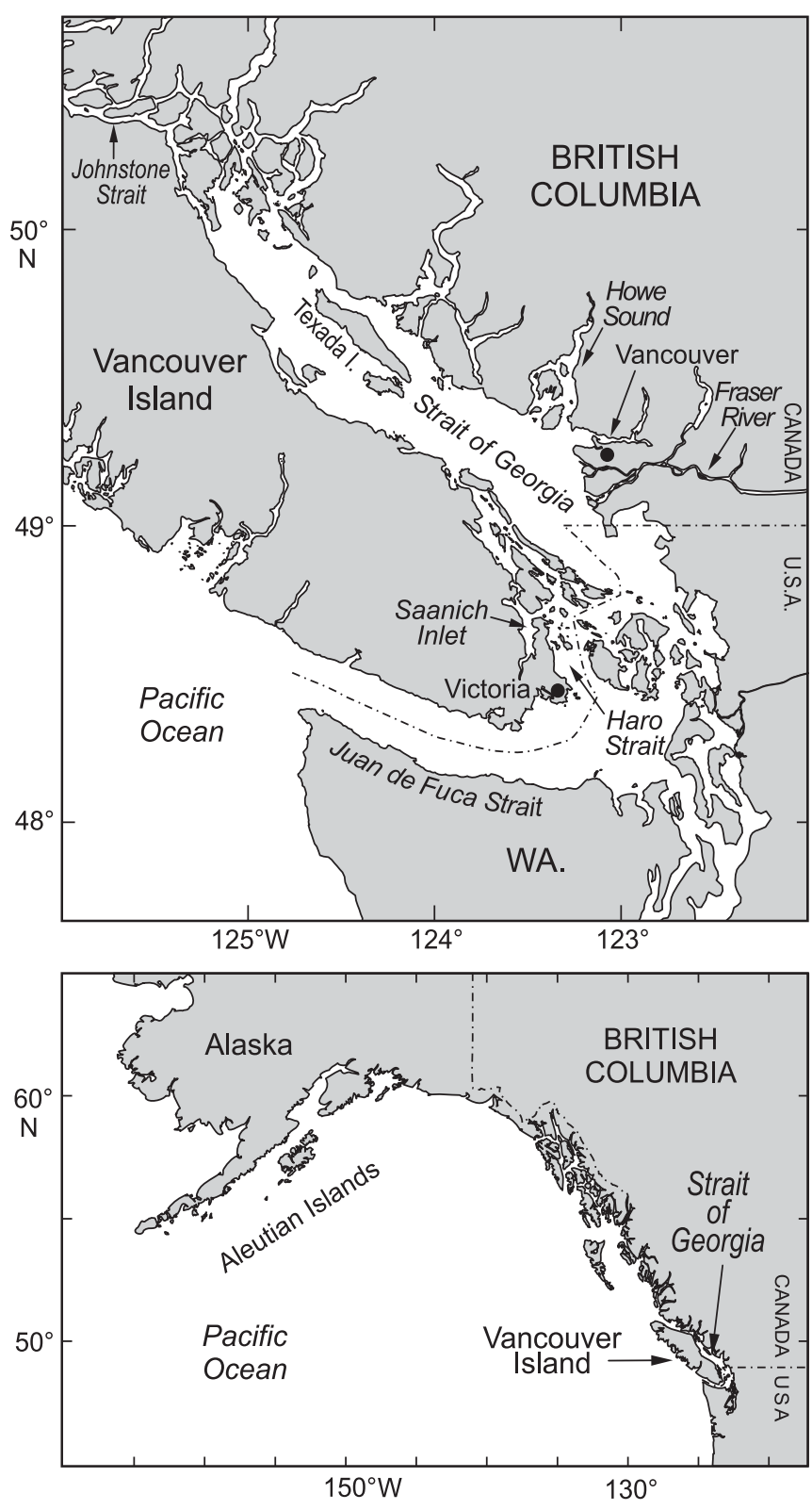

Fig. 1. Regional map showing the Strait of Georgia and the Fraser River drainage basin

functioning of this coastal sea specifically to identify points of sensitivity to change. Coastal environments have already changed due to human activities, and the natural baseline against which to assess trends may be difficult to determine (Pitcher 2001, Robinson \& Frid 2008). Change is a result of complex interactions among physical, geochemical and biological factors, with feedbacks providing opportunities for surprises. To approach the problem of complexity, we start with physical and geochemical forcing and human pressures before addressing biological responses. We seek thresholds or mechanisms of change that contain particularly strong possibilities to produce alterations significant to local biogeochemical cycles and to humans. The conclusions drawn for the Strait of Georgia may be extrapolated to other coastal basins with similar characteristics (i.e. typologies; Buddemeier et al. 2008).

\subsection{Strait of Georgia}

The Strait of Georgia lies between mainland British Columbia and Vancouver Island (Fig. 1). Shallow sills $(\sim 100 \mathrm{~m})$ restrict water exchange with the Pacific Ocean predominantly at the southern end and secondarily at the northern end of the strait. Over the Holocene, the strait has been subject to considerable fluctuation in relative sea level (RSL), with greater stability during the past few millennia (Thomson 1981). Emergence of land has also been recognized in the oral tradition of the Saanich Peoples: 'Saanich' (WSÁNEĆ) means 'raised' in Coast Salish (Paul et al. 1995). The Fraser River is the dominant source of fresh water and particles to the strait, contributing approximately $73 \%$ of the $158 \times 10^{9} \mathrm{~m}^{3} \mathrm{yr}^{-1}$ of water and $64 \%$ of the $30 \times 10^{9} \mathrm{~kg} \mathrm{yr}^{-1}$ of particles (Johannessen et al. 2003). Bordering the strait are many large towns, including Metro Vancouver (population $\sim 2$ million), and numerous industries (Fig. 1).

\subsection{Projected regional changes}

Climate change projections vary regionally; the poles exhibit enhanced warming, for example, and coasts respond differently than interior continental regions. On the west coast of North America, we expect drier summers, wetter winters and more extremes in temperature and precipitation (IPCC 2007b). From November to April, more precipitation will fall as rain and less as snow. Models and observations suggest that glacial ice and permanent snow mass, key stabilizers of the hydrological cycle (Barnett et al. 2005), will decrease. Rivers discharging to Canada's west coast are dominated by snow and ice melt. Together, the seasonal shift in precipitation and the loss of long-term storage in snow and ice will lead to a more even hydrograph, with a smaller freshet and greater fall and winter flow. The Strait of Georgia receives a dominant imprint of its water properties by advection from the continental shelf, so changes in shelf water properties may be imported rapidly $(<1 \mathrm{yr})$ into the strait. A simple way to effect change in shelf waters would be to alter the frequency and intensity of coastal upwelling or the composition of the upwelled water. 


\section{PHYSICAL FORCING AND SENSITIVITY TO CHANGE}

\subsection{Water motion and exchange}

Water movement in the strait is dominated by estuarine circulation driven primarily by the Fraser River, as well as by tides and winds (Thomson 1981, Masson 2006). Bottom water in the Strait of Georgia has the longest residence time ( 1 yr; Waldichuk 1957), while surface water has the potential to exchange within weeks (Pawlowicz et al. 2007). Bottom-water replacement occurs through deep-water renewal events timed with neap tides in late spring and summer (Waldichuk 1957, Masson \& Cummins 2000). Change in water properties including temperature, dissolved oxygen (DO), nutrients and $\mathrm{pH}$ can therefore be imported to the strait from the continental shelf (Fig. 2).

\subsection{Seawater temperature}

Average air temperatures in British Columbia have increased significantly over the last 50 yr (IPCC 2007a). Due to its heat capacity, the rise in ocean temperature lags those of air, river and lake water (IPCC 2007b). Nevertheless, seawater in the Strait of Georgia has warmed since 1970 (Fig. 3). All the seawater that enters the basin (up to $460 \mathrm{~m}$ deep) must flow over shallow sills $(<100 \mathrm{~m})$, and since the temperature increase at depth parallels the temperature rise in the surface waters (upper $150 \mathrm{~m}$ ) of the shelf (Masson \& Cummins 2007), we infer that heat in the bottom waters is imported from the shelf. El Niño events also transport warm waters northward along the coast of western North America, producing episodic warming in addition to the long-term trend (Masson \& Cummins 2007).

\subsection{Rivers and the hydrological cycle}

Freshwater runoff drives estuarine circulation, supports stratification in the strait and supplies dissolved and particulate substances. River discharge to the Strait of Georgia is strongly seasonal: snow-fed rivers, including the Fraser River, peak in the early summer, while the much smaller, rain-fed rivers of Vancouver Island peak in the winter.

The Fraser River's discharge is changing. Summer peak flow has decreased, winter flow has increased and freshet has tended to occur earlier (Fig. 4a; Morrison et al. 2002). These observed trends are projected to continue throughout the 21st century, as the discharge shifts from snowmelt- toward rainfall-dominant runoff (Whitfield et al. 2003), with a significantly lower peak flow occurring about $24 \mathrm{~d}$ earlier by 2080 than during the 1961 to 1990 reference period (Fig. 4b). River flow is projected to become more variable (Morrison et al. 2002), as has already been observed in short-term $(<6 \mathrm{~h})$ precipitation intensity over the last $10 \mathrm{yr}$ in the Vancouver area (Jakob et al. 2003).

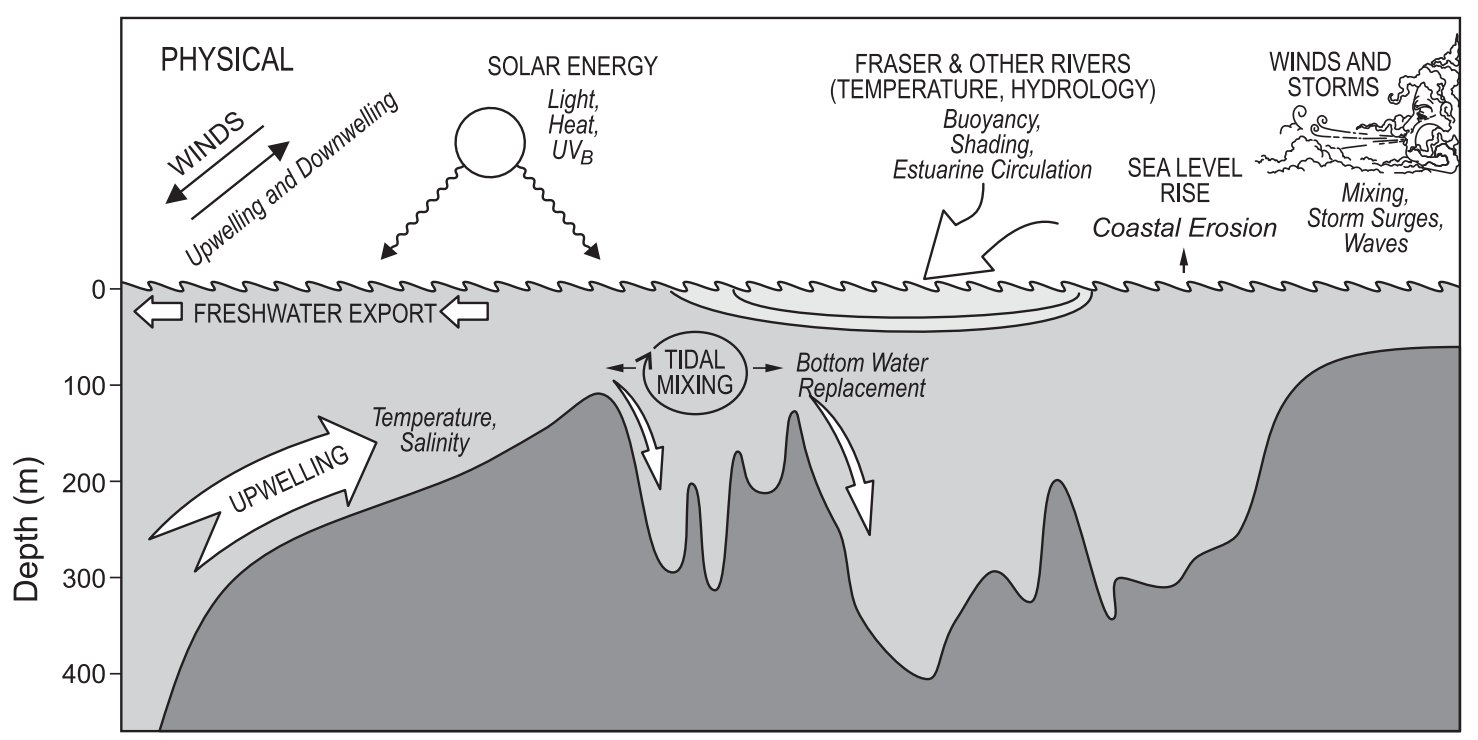

Fig. 2. Schematic diagram showing physical factors (in capitals) that are subject to climate change and the range of physical properties/processes (in italics) they are likely to impact in the Strait of Georgia. Changes in upwelling on the continental shelf will affect the temperature and salinity of replacement water for the basin. Changes in the timing of freshwater inflow will alter stability of surface waters. Storms together with sea level rise will lead to coastal erosion and inundation of nearshore regions of low topography. Factors like solar energy and tidal mixing are less subject to change over century timescales 


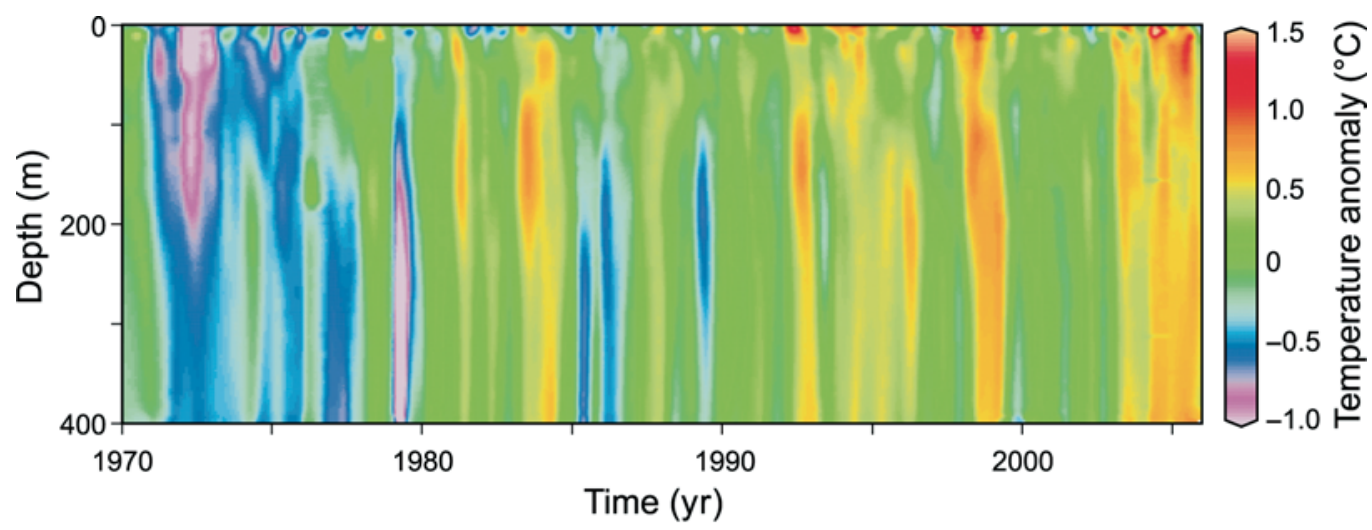

Fig. 3. The warming of seawater in the Strait of Georgia since 1970 (adapted from Masson \& Cummins 2007)

The temperature of major rivers draining into the Georgia Basin is also increasing. In the summer of 2006, 9 new daily high temperature records were set in the Fraser River. The summer temperature of the Fraser River is expected to rise by $1.9^{\circ} \mathrm{C}$ by the end of the century (Morrison et al. 2002), leading to maximum temperatures approaching $24^{\circ} \mathrm{C}$.

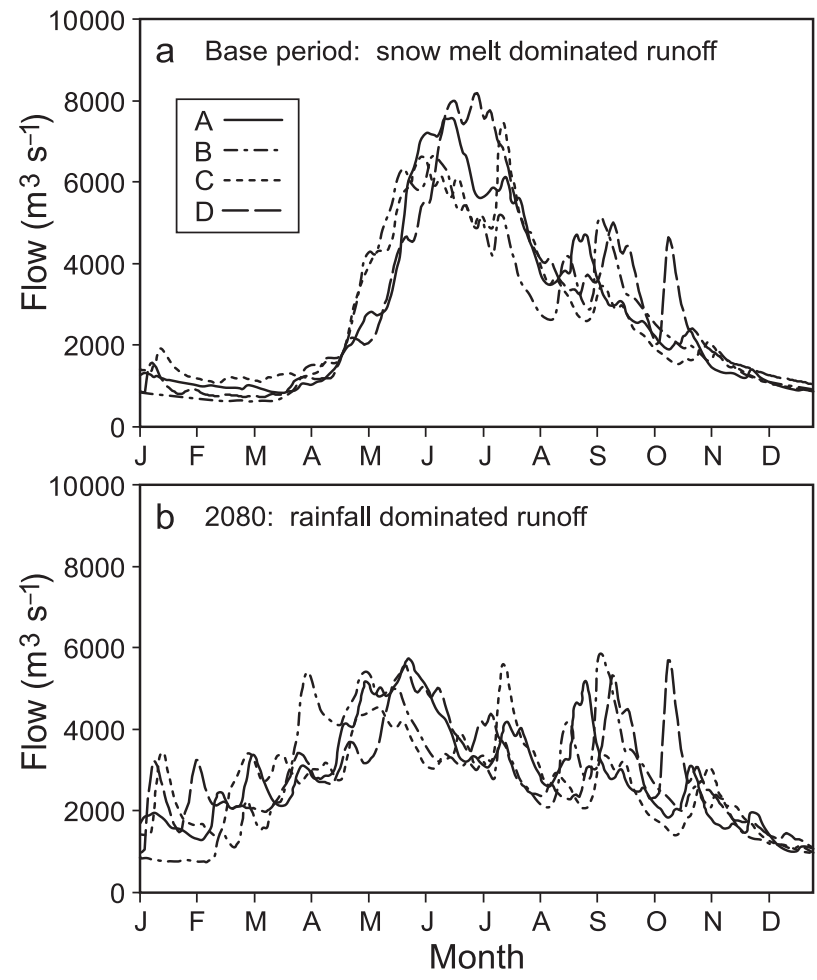

Fig. 4. (a) Present timing of the Fraser River hydrograph, dominated by spring snow melt, and (b) future hydrograph where rainfall becomes more important, leading to a more modest freshet and higher flows in the fall (adapted from Morrison et al. 2002). The date of the actual peak flow is not plotted, because that date can be affected by a single large rainstorm (J. Morrison pers. comm. 2008). A, B, C and D represent 4 model runs

\section{GEOCHEMICAL FORCING, RESPONSES AND SENSITIVITY TO CHANGE}

In this section we consider factors that affect chemical cycles, especially those of organic carbon (OC), which can then affect oxygen, productivity and the geochemical cycles of elements affected by redox conditions (DO, hypoxia, sulphide production).

\subsection{Light climate}

Visible and UV radiation is, strictly speaking, a physical forcing. We include it here because its penetration into the water is largely controlled by geochemical transformations of organic matter. Furthermore, light and nutrients provide the means to produce OC through primary production (PP), to destroy or modify OC through photochemistry, to alter carbon flow in ecosystems through, for example, UV damage, and to affect the distribution of oxygen through organic production and remineralization. The 2 most important geochemical controls on UV are suspended particles and coloured dissolved organic matter (CDOM).

\subsection{Particle processes}

Particle processes have been studied extensively in the Strait of Georgia (e.g. Hill et al. 2008). The Fraser River supplies about $80 \%$ of the particle loading to the strait (Johannessen et al. 2003), and, although these particles are predominantly inorganic, the $\sim 1 \%$ OC carried by riverborne particles provides almost half of the particulate organic carbon (POC) that enters the strait. Particle discharge by the Fraser River is highly seasonal, with most of the load borne during early freshet, at which time sand makes up about half of the suspended particles. During the rest 
of the year, smaller particles predominate. Sand settles first to nourish the Fraser Delta, whereas finer particles are transported farther in a surface plume ( $<15 \mathrm{~m}$ thick) that may extend over most of the southern and central Strait of Georgia (Johannessen et al. 2006), limiting light penetration. Once the plume reaches Haro Strait, intense tidal mixing stirs the particles and holds them in suspension throughout the water column. Despite the apparent extent of turbidity in surface waters, most of the particulate matter and, hence, associated materials (OC, contaminants) are trapped within basin sediments (Johannessen et al. 2003).

Organic particles are also produced within the strait through PP (Fig. 5a). About $20 \%$ of the PP and terrigenous carbon is oxidized either in the water column or sediments (Johannessen et al. 2003) and the rest is buried. OC from terrestrial runoff and PP enters near the ocean surface, affecting light and the exchange of $\mathrm{CO}_{2}$ with the atmosphere, but much of the remineralization takes place at depth, affecting the distribution of oxygen.
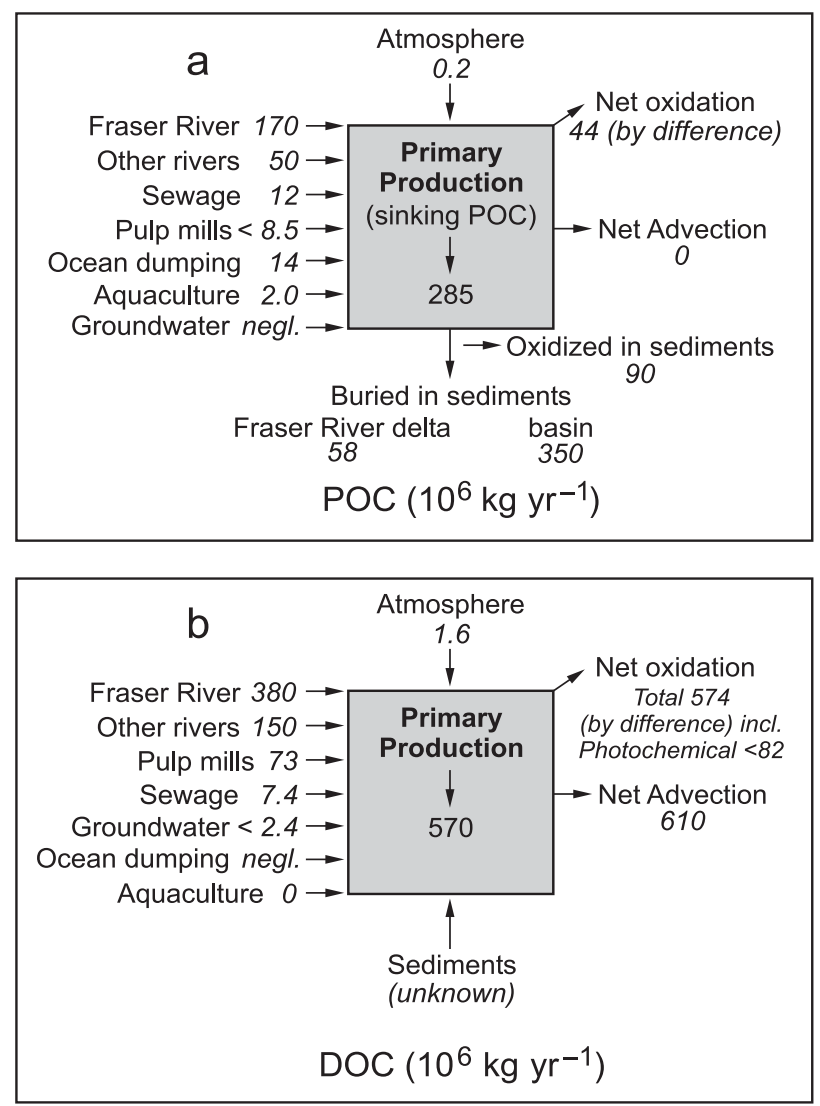

Fig. 5. Sources of (a) particulate organic carbon (POC) and (b) dissolved organic carbon (DOC) in the Strait of Georgia (adapted from Johannessen et al. 2003, 2008b). Note that anthropogenic loadings account for only a small portion of the organic carbon. negl. = negligible

\subsection{Dissolved organic matter}

In coastal locations with large terrigenous input, CDOM may make up 10 to $90 \%$ of the dissolved organic matter (DOM) (Thurman 1985); certainly, the water in the Fraser plume is visibly coloured. Lacking CDOM data for the strait, we rely on the distribution of DOC as a proxy for which we have strait-wide seasonal data (Johannessen et al. 2008b). Most of the OC in the Strait of Georgia is dissolved (Fig. 5). As with POC, the 2 major sources of DOC to the strait are PP and terrestrial runoff (Johannessen et al. 2003). Rainwater likely provides a negligible source of DOM (Willey et al. 2000), but there are no rainwater data for the strait. DOM may sustain microbial ecosystems or undergo chemical/photochemical reactions, but these processes have not been quantified locally. Johannessen et al. (2008b; Fig. 5) estimate that about twice as much DOM passes through the strait each year as is contained in the standing inventory, implying that DOM is highly dynamic and is, therefore, vulnerable to change.

\subsection{Nutrients}

Nitrogen is thought to be the controlling nutrient for PP in west coast waters (Mackas \& Harrison 1997). Nitrogen supply in the Strait of Georgia and the Juan de Fuca and Haro Straits is dominated by the upwelling of nutrient-rich water onto the continental shelf and the inflow of these waters at depth into the strait driven by estuarine circulation (Fig. 6; Mackas \& Harrison 1997). Unlike many coastal regions where eutrophication stems from riverine and coastal inputs, the natural marine nutrient supply swamps anthropogenic loadings, ensuring that phytoplankton are never nutrient limited ( $\left[\mathrm{NO}_{3}\right]$ always $>10 \mu \mathrm{M}$; Mackas \& Harrison 1997) in the Juan de Fuca Strait and the southern Strait of Georgia. Periodic nutrient limitation does occur in the central Strait of Georgia during the summer, however, and the fjords and inlets are sensitive to the addition of anthropogenic nutrients due to restricted circulation and remoteness from upwelled water (Mackas \& Harrison 1997). The concentration of nitrate in Fraser River water is low (Yin et al. 1995), but entrainment of subsurface water by estuarine circulation forced by the Fraser River provides a significant supply of ocean nutrients to the euphotic zone (Yin et al. 1995), with higher river flow sustaining more entrainment, even on the timescale of a few days. The stability provided by runoff promotes the initiation of PP in the spring, although later this stability limits the resupply of nutrients from below (St. John et al. 1993). Wind-mixing modulates estuarine circulation by breaking down stratification and re-supplying nutrients on a 


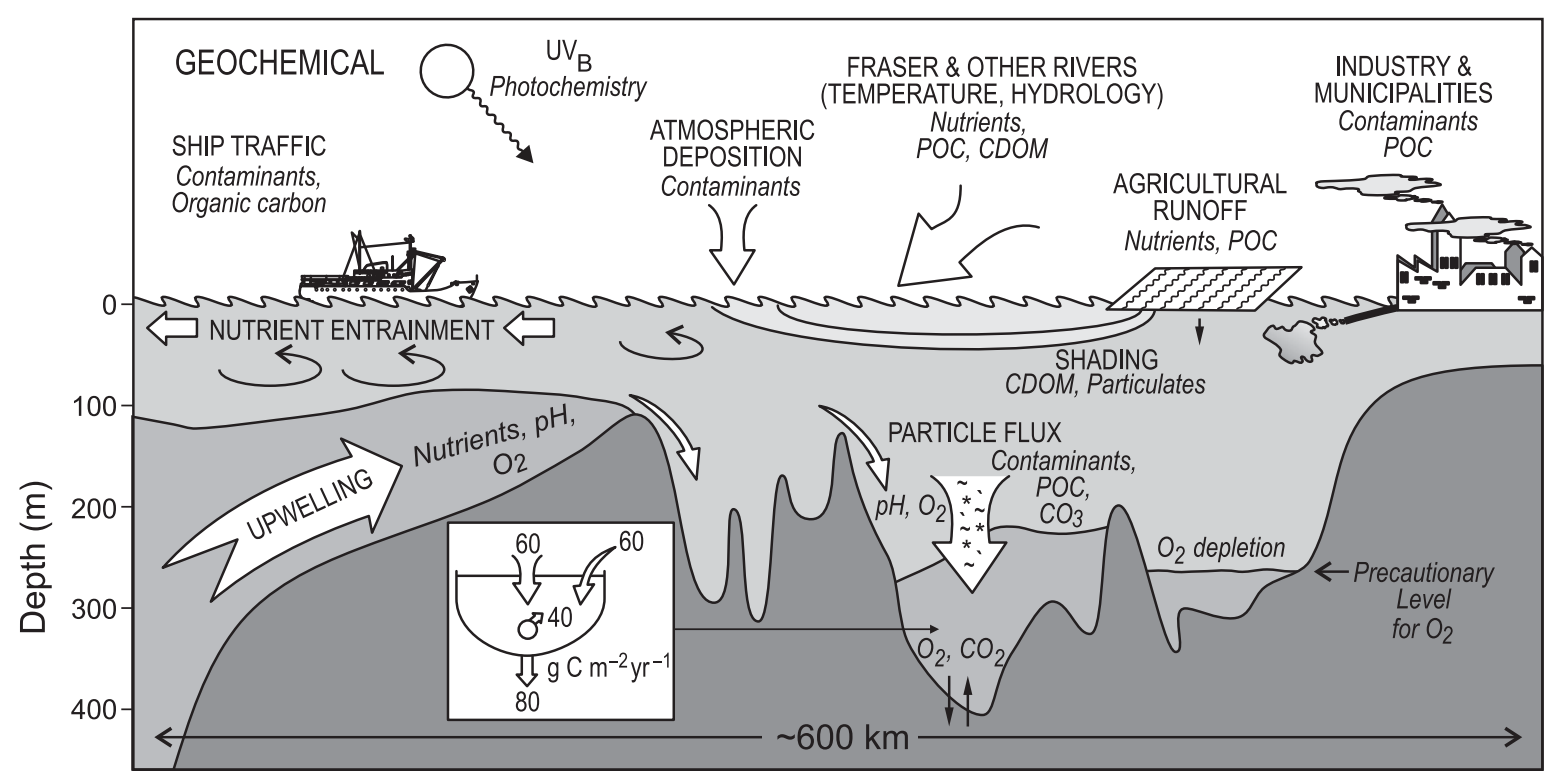

Fig. 6. Schematic diagram showing geochemical factors (in capitals) subject to climate change and the range of properties or processes (in italic) they are likely to impact. Upwelled water at the coast carries low dissolved oxygen and low $\mathrm{pH}$, which then set a baseline for Strait of Georgia bottom waters. Sinking particles containing labile organic carbon (marine and terrigenous sources) further decrease bottom water $\mathrm{O}_{2}$ and $\mathrm{pH}$ through metabolism, which converts $\mathrm{O}_{2}$ to $\mathrm{CO}_{2}$. Disturbances to the natural setting include nutrients, organic loadings and contaminants. The inset diagram shows an organic carbon budget for basin waters (>200 m depth) based on Johannessen et al. (2003, 2005b). The metabolism of $40 \mathrm{~g} \mathrm{C} \mathrm{m}^{-2} \mathrm{yr}^{-1}$ in basin waters is equivalent to a drawdown of $\sim 0.7 \mathrm{ml} \mathrm{l}^{-1} \mathrm{yr}^{-1}$ of $\mathrm{O}_{2}$. The precautionary level for $\mathrm{O}_{2}\left(\sim 3.2 \mathrm{ml}^{-1}\right)$, below which animals begin to exhibit the effects of hypoxia (see Vaquer-Sunyer \& Duarte 2008), is from Masson (2006)

short timescale. No trend in nutrient concentrations has been observed over the period of recent monitoring (2002 to 2006) (DFO 2007).

\subsection{Dissolved oxygen}

Geochemical cycling is controlled by DO directly through sequestration or remobilization of elements sensitive to sulphide or oxygen concentration and indirectly through the regulation of biological populations, which then affect organic cycling and biomixing. At the surface of the Strait of Georgia, DO exchanges with the atmosphere and is produced in the water by phytoplankton. The spring bloom each year boosts the surface concentration of DO by about $2 \mathrm{ml} \mathrm{l}^{-1}$ (Masson \& Cummins 2007). Year-round the concentration in surface waters is high ( 7 to $9 \mathrm{ml} \mathrm{l}^{-1}$ ) and decreases with depth (Masson \& Cummins 2007). At depth, DO is periodically re-supplied during deep-water renewal in the late spring and summer (Masson 2002), which opposes a relentless drawdown due to the oxidation of organic matter supplied from above, leading to a seasonal cycle in deep-water DO (Fig. 7). Between December and March, the concentration of oxygen in the deep central strait can be as low as $2 \mathrm{ml} \mathrm{l}^{-1}$ (Masson \& Cummins 2007). Given that $4.6 \mathrm{mg} \mathrm{l}^{-1}\left(3.2 \mathrm{ml} \mathrm{l}^{-1}\right)$ is pro- posed as a precautionary level for hypoxic effects, and $2 \mathrm{mg} \mathrm{l}^{-1}\left(1.4 \mathrm{ml}^{-1}\right)$ is considered sufficiently hypoxic to cause 'dead zones' (Vaquer-Sunyer \& Duarte 2008), a small decrease in the Strait of Georgia's bottom-water DO has the potential to alter species distributions by elimination or restriction.

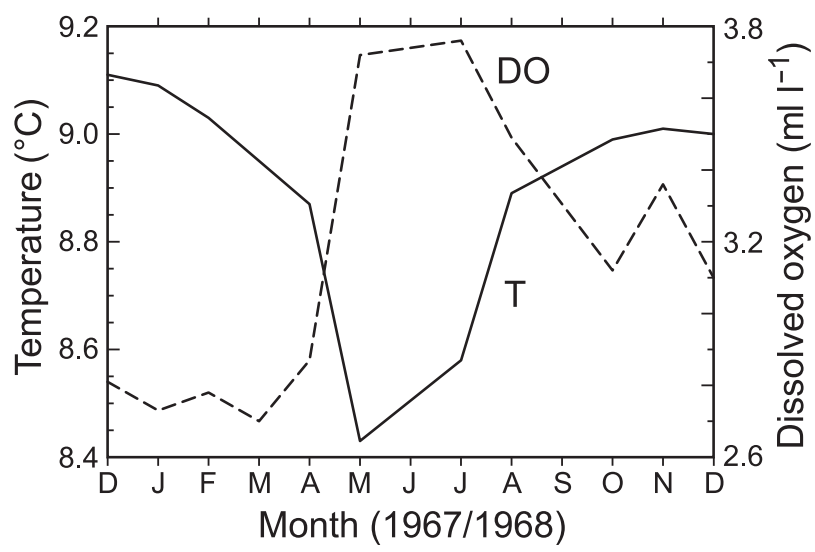

Fig. 7. Average monthly values of dissolved oxygen (DO) and temperature $(\mathrm{T})$ in bottom waters of the Strait of Georgia for 1967/1968 (from Masson \& Cummins 2000). Lowest $O_{2}$ values are recorded during winter, while lowest temperatures are recorded in spring to summer. In some years DO dropped to $2 \mathrm{ml} \mathrm{l}^{-1}$ (Masson \& Cummins 2007), which is considered sufficiently hypoxic to cause 'dead zones' 
The deep Strait of Georgia has never been anoxic in recorded history, although bottom waters in nearby fjords (Saanich Inlet, Howe Sound) have exhibited seasonal or intermittent anoxia. For the strait, the oxygen concentration has decreased by 0.02 to $0.03 \mathrm{ml} \mathrm{l}^{-1} \mathrm{yr}^{-1}$ over the period 1970-2006 (Masson \& Cummins 2007). A quarter of this decrease can be explained directly by the decrease in solubility due to the warming of seawater (at a basin water temperature of $9^{\circ} \mathrm{C}$ and a salinity of 33 , a $1^{\circ} \mathrm{C}$ increase in temperature implies a $0.15 \mathrm{ml} \mathrm{l}^{-1}$ decrease in $\mathrm{O}_{2}$ ). The remaining decrease is likely derived from other processes. The concentration of DO in surface waters of the shelf off Vancouver Island has recently been decreasing (Whitney et al. 2007). This oxygen drawdown could be imported into the strait's basin water as described earlier. The system, and others with similar bathymetry, is particularly vulnerable because the shallow sills permit the entry of eastern Pacific Ocean shelf and slope water, which exhibits a strong $\mathrm{O}_{2}$ minimum. Within the strait, processes that increase the flux of labile carbon into basin waters could, likewise, lead to a decrease in DO. The oxidation of $40 \mathrm{~g} \mathrm{C} \mathrm{m}^{-2} \mathrm{yr}^{-1}$ (inset panel in Fig. 6) is equivalent to a drawdown of $\sim 0.7 \mathrm{ml} \mathrm{l}^{-1} \mathrm{O}_{2}$ : a failure in renewal for a 2 to 3 yr period would lead to anoxia in deep water.

\section{6. $\mathrm{pH}$}

Acidification of the ocean through uptake of anthropogenic $\mathrm{CO}_{2}$ alters chemical speciation and biogeochemical cycling for many elements and compounds, in particular increasing the availability of some toxic metal ions, such as the cupric ion (Knutzen 1981). The best known effect of low $\mathrm{pH}$ is dissolution of carbonate shells (Wootton et al. 2008, Doney et al. 2009), although there are other possible physiological effects (Widdicombe \& Spicer 2008). Plants and animals at risk include calcareous plankton (coccolithophores), bivalves (clams, mussels), corals and a number of benthic invertebrates (Knutzen 1981, Fabry et al. 2008). The decrease in $\mathrm{pH}$ associated with even a moderate increase in atmospheric $\mathrm{pCO}_{2}$ of $200 \mathrm{ppmv}$ reduces the growth rate of gastropods and sea urchins (Shirayama \& Thornton 2005). Marine fish seem to be relatively insensitive to changes in $\mathrm{pH}$, but less active fish, such as bottom feeders, are thought to be at greater risk for disruption of their acid-base balance (Fabry et al. 2008), and indirect effects on the food web due to loss of carbonate species could produce unexpected ecological consequences, especially for nearshore benthic ecosystems (Wootton et al. 2008). A decrease in $\mathrm{pH}$ could affect fish survival at sea by reducing the availability of calcium-rich food (e.g. pteropods; Doney et al. 2009). Non-calcareous algae and sea grasses may thrive in high- $\mathrm{CO}_{2}$, low-pH conditions (Hall-Spencer et al. 2008), as may jellyfish (Fabry et al. 2008). It is possible that the strait of Georgia will experience shifts in its species assemblage and reductions in its biodiversity, related to $\mathrm{pH}$ decline.

In contrast to the situation in the open ocean, the $\mathrm{pH}$ decrease in the strait is unlikely to begin at the surface, but will rather impinge on deep waters first, as low-pH water intrudes from the continental shelf. Furthermore, oxygen drawdown produces $\mathrm{CO}_{2}$, further reducing $\mathrm{pH}$. Recent data collected for the North American west coast shelf shows that upwelling brings with it acidified water from intermediate depth (Feely et al. 2008), with the possibility that upwelling events will supply low-pH water to the Strait of Georgia via deepwater renewal. There are no trend data available for $\mathrm{pH}$ in the Strait of Georgia. Increased water temperature and reduced oxygen are thought to act synergistically with reduced $\mathrm{pH}$ to stress marine animals further (Shirayama \& Thornton 2005, Fabry et al. 2008).

\section{HUMAN FORCING OTHER THAN GLOBAL CLIMATE CHANGE}

Within the Strait of Georgia, known threats to the marine ecosystem include contamination by a wide range of chemicals and plastics, fishing, habitat destruction, ship traffic and the introduction of invasive species.

\subsection{Contaminants}

Contaminants enter the coastal ocean through longrange transport and local discharges, both of which have been identified for the Strait of Georgia (Johannessen et al. 2008a and references therein). Urbanization, industry and agriculture along the shores of the Strait of Georgia and adjacent inlets have resulted in contamination by metals, organic pollutants, other chemicals and pathogens. The long history of contaminants entering the strait is evident in marine sediment core records of chemicals like PCBs (polychlorinated biphenyls), PBDEs (polybrominated diphenylethers), dioxins and furans (Macdonald et al. 1992, Johannessen et al. 2008a), polynuclear aromatic hydrocarbons (Yunker et al. 1999), metals (Macdonald et al. 1991, Johannessen et al. 2005a), tri-butyl tin (TBT) (Stewart \& Thompson 1994) and industrial detergents (Shang et al. 1999). Many of these contaminants exhibit a characteristic temporal trend, with an initial entry date, an increase to a maximum and then a decrease subsequent to regulation (Fig. 8). However, PBDEs are still in the growth phase (Johannessen et al. 


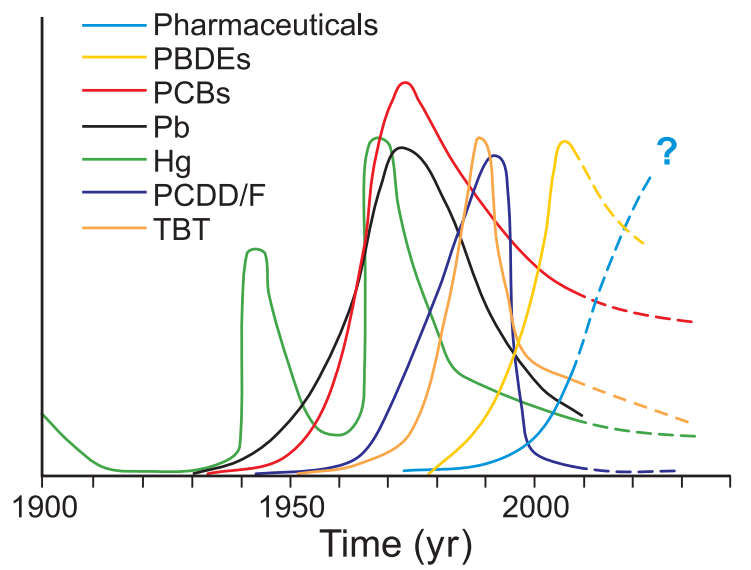

Fig. 8. A schematic representation of the time lines for selected contaminant exposures in the Strait of Georgia (not drawn to scale in terms of toxicological importance; data sources: Macdonald et al. 1991, 1992, Stewart \& Thompson 1994, Johannessen et al. 2005a, 2008a). PBDE: polybrominated diphenylethers; PCB: polychlorinated biphenyls; PCDD/ F: dioxins and furans; TBT: tri-butyl tin

2008a), and new chemicals like pharmaceuticals (Hirsch et al. 1999, Muir \& Howard 2006) will pose future threats. Contaminants that bioaccumulate and biomagnify present greater risk, because they can reach toxic concentrations at high trophic levels (Ross et al. 2000).

Structural pollutants, such as fishing gear and plastic, threaten marine organisms, especially fish, mammals and birds, through choking, smothering and ingestion (Moore 2008). The effect of plastic has not been quantified systematically in the Strait of Georgia, but it has been implicated in numerous marine mammal strandings (P. Ross, Fisheries and Oceans Canada, pers. comm., July 2008). We expect plastics to present a significant and increasing risk in this semi-enclosed sea bounded by industry and a large human population.

\subsection{Fishing}

About $80 \mathrm{Mt}$ of fish are extracted annually from global oceans (Pauly et al. 2003), along with a further $\sim 27$ Mt of fish bycatch (see Alverson et al. 1994, who note other bycatch including birds, turtles and mammals). Fishing not only draws down the target species but has wider effects on the ecosystem (Pitcher 2001). The present scale of extraction has resulted in measurable changes in the global marine trophic structure (Myers \& Worm 2003). These changes may manifest themselves in, for example, a change in the balance between slow-growing fish and those that reproduce more quickly, or the removal of certain predators, leading to a new predominance of jellyfish (Pitcher 2001).
Fishing can also lead to habitat destruction and instability in populations (Anderson et al. 2008). For the strait, benthic invertebrates, fishes and marine mammals have been fished commercially since the late 1800 s, leading to declines in many species, the extirpation of baleen whales and the virtual extirpation of sturgeon (Wallace 1998). Currently, Fisheries and Oceans Canada manages the harvest of marine resources, balancing conservation with aboriginal, commercial and sports fisheries.

\subsection{Habitat destruction}

Habitat destruction in coastal regions results in hydrological and biogeochemical changes (Andrews et al. 2006). Fish, intertidal organisms, marine birds and other species are threatened by the loss of coastal habitat, which has already changed significantly around the strait over the last century; surveyed marshes have all lost area since the 1880s (Levings \& Thom 1994). In the Fraser estuary and lower river, the loss of salt marshes, bogs, wet meadows, and the Sumas flood plain lake has been partially offset by gains in brackish and freshwater marshes due to mudflat accretion.

Building jetties, causeways, seawalls and other structures along the edge of the water and changing the course of rivers interfere with natural sediment movement, eroding beaches and mudflats and endangering coastal communities. Hard edges like seawalls and dykes and the extensive channelization of rivers in the Pacific northwest also hinder the migration of salmon upstream.

Climate change interacts with urbanization to accelerate the loss of habitat. Many areas of the Lower Mainland are vulnerable to flooding (Fig. 9), which is likely to occur as a result of global sea level rise (SLR), local delta subsidence (Shaw et al. 1998) and increased incidence or intensity of storms and storm surge.

\subsection{Marine traffic}

Marine traffic is associated with negative effects like noise, collisions with animals, contaminants and invasive species, and is one of the 3 main threats to endangered resident killer whales (DFO 2008). Contaminants released by shipping include oil, other chemicals and plastics, and antifoulant leachate (e.g. $\mathrm{Cu}$, TBT) from ships' hulls. Given large international ports (Vancouver, Seattle), a sheltered inland sea, and a number of population centers distributed among coastal inlets and islands, marine traffic is heavy within the Strait of Georgia (Fig. 10; MOE 2006). Between 1996 and 2004, marine traffic remained stable at about 400000 to 

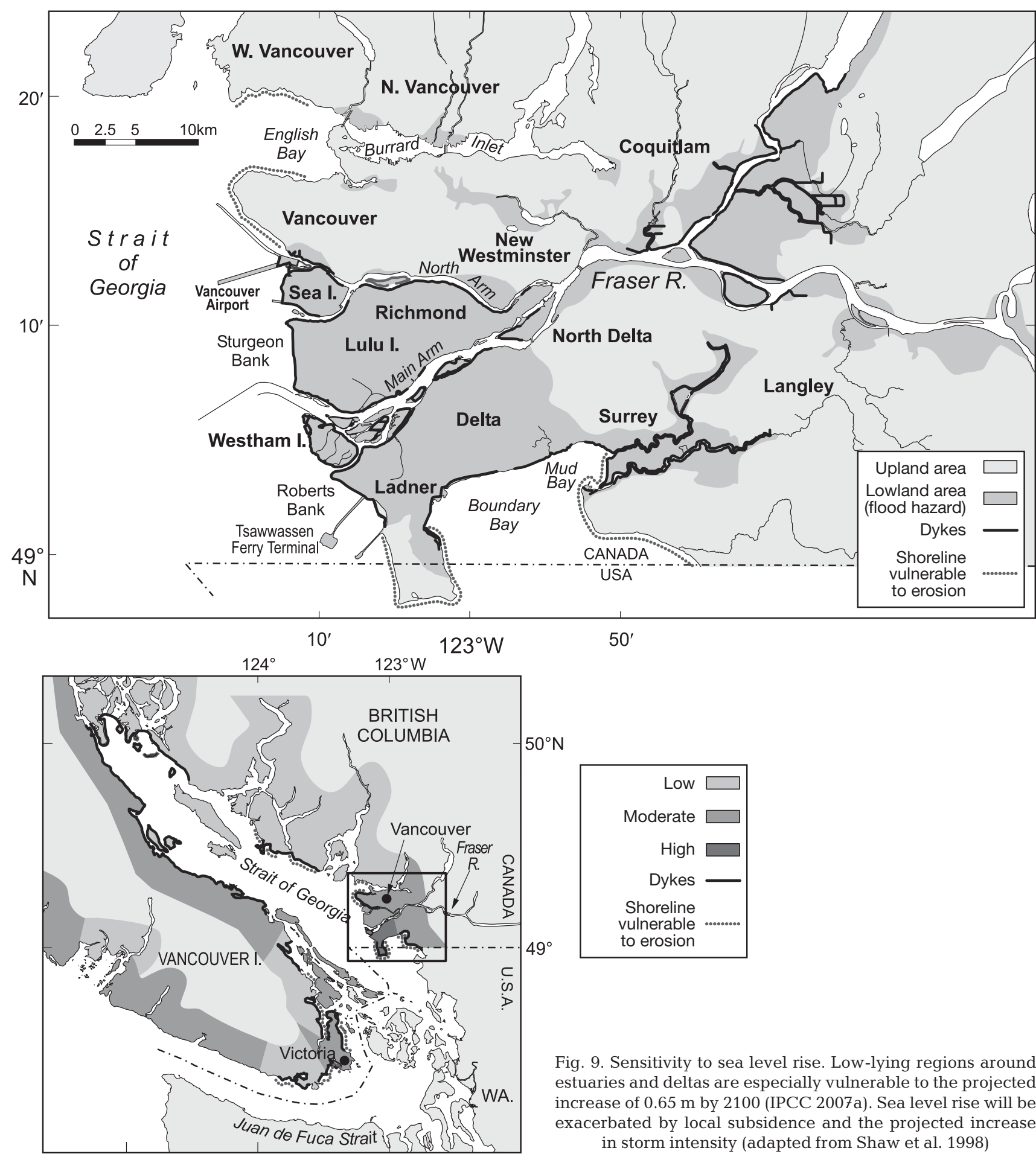

$50^{\prime}$

$50^{\circ} \mathrm{N}$

\begin{tabular}{|c|}
\hline Low $\square$ \\
Moderate $\square$ \\
High $\square$ \\
Dykes $\square$ \\
Shoreline \\
vulnerable ......... \\
to erosion
\end{tabular}

450000 vessel movements $\mathrm{yr}^{-1}$, where a 'movement' is defined as one uniquely identifiable ship observation per $25 \mathrm{~km}^{2}$ grid cell. Ferries and cruise ships (56\%) account for most of the traffic, followed by tugs $(29 \%)$, cargo $(7 \%)$, fishing $(3 \%)$ and all others $(5 \%)$. Tanker and chemical traffic account each for $<1 \%$. Noise from ship propulsion systems is ubiquitous in the strait, its effects on ecosystems remain unevaluated, and it is likely to continue to increase. The increased noise from traffic will be exacerbated by declining $\mathrm{pH}$, which alters chemical equilibria to decrease sound absorption (12 to $40 \%$; Hester et al. 2008). 


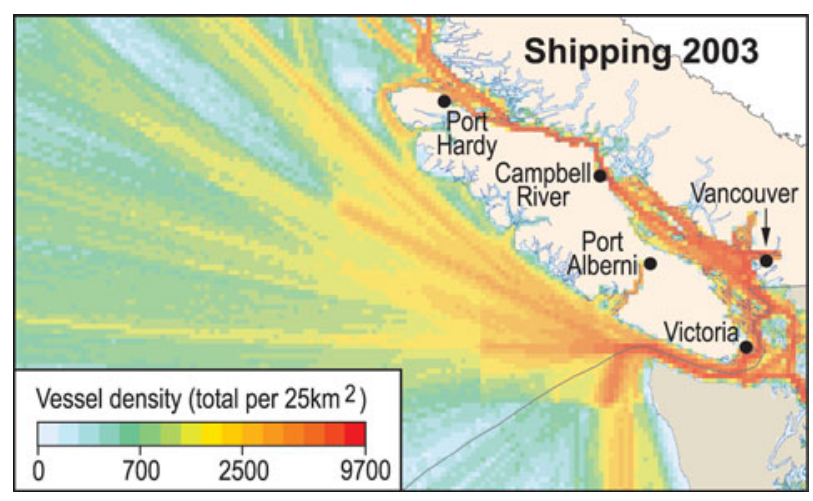

Fig. 10. Density of marine traffic in the Strait of Georgia for 2003 (adapted from MOE 2006)

\subsection{Invasive species}

Invasive species threaten ecosystems through competition with native species, habitat modification, predation, hybridization and other mechanisms (Heath et al. 1995, Levings et al. 2002). Alien species (both invasive and non-threatening) have been introduced deliberately, as in the case of the eastern and Pacific oysters Crassostrea virginica and C. gigas, the mussels Mytilus edulis and M. galloprovincialis, and the scallop Mizuhopecten yessoensis, which were imported into the Strait of Georgia for aquaculture. More frequently, species arrive unintentionally, in or on ships (solid ballast, ballast water, hull fouling), with other introduced species, through the trade in live food and plants (Gillespie 2007) or through expansion of range as a result of ocean climate change. Alien species in the strait have increased 40 -fold over the last century (Fig. 11) to a tally of 89 species as of 2002 (Levings et al. 2002). These species include phytoplankton and macroalgae, invertebrates, fishes, birds and mammals, with over one-third being intertidal (Gillespie 2007).

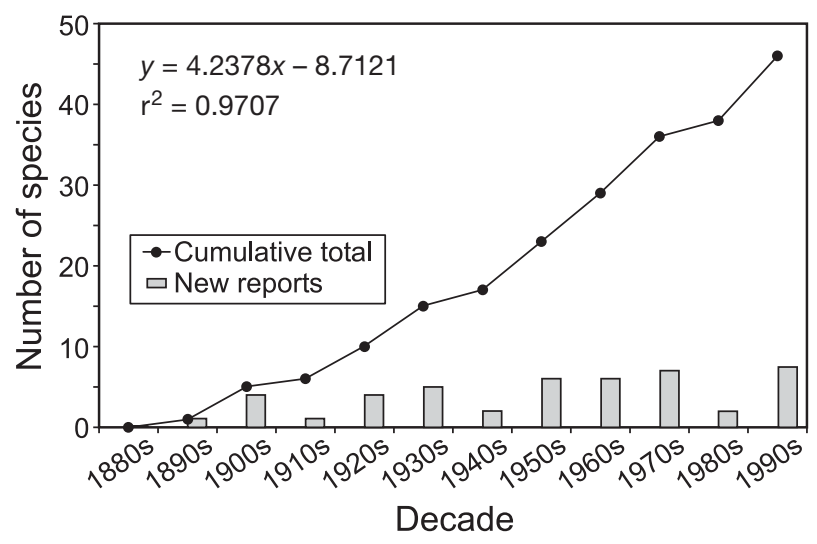

Fig. 11. Cumulative and annual new reports of invasive species in the Strait of Georgia (adapted from Levings 2002)
The concentration of aquaculture, estuarine circulation patterns and the increasingly intensive international shipping in the southern strait have likely contributed to the large number of alien species.

Climate change, contaminants and other pressures on local biota play important collaborative roles with alien species by stressing indigenous species and/or by pushing them away from the centre and toward the margin of their natural biogeographical domains (Couillard et al. 2008). Stressed, for example, by temperature, salinity, or oxygen concentration, local species may no longer be able to compete with an invasive species better adapted to the changed circumstances, with the result that a spectacular shift in population can occur (Occhipinti-Ambrogi 2007).

\section{BIOLOGICAL RESPONSES AND SENSITIVITY TO CHANGE}

The Strait of Georgia supports productive benthic and pelagic food webs, including commercially fished species and marine mammals. Biota are exposed to the cumulative effects of physical, geochemical and human forcings. In this section, we discuss the status of and observed changes in each group, projecting those changes forward in the context of climate change.

\subsection{Phytoplankton}

Phytoplankton production is high, but extremely patchy in time and space, leading to estimates of total PP that vary from 120 to $345 \mathrm{~g} \mathrm{C} \mathrm{m}^{-2} \mathrm{yr}^{-1}$ (e.g. Parsons et al. 1980, Harrison et al. 1983). Productivity is highest at fronts, including those with high tidal energy (Haro Strait and Johnstone Strait) and those associated with the Fraser River plume (e.g. Parsons et al. 1980, Harrison et al. 1983). The timing and intensity of wind events, which break down stratification and mix nutrients back into the photic zone, are also critical to where and when PP occurs in the strait (St. John et al. 1993).

The Strait of Georgia exhibits intermittent blooms lasting a few days throughout spring and summer (A. Peña, IOS, DFO, unpubl. data; J. Gower, IOS, DFO, unpubl. data; Fig. 12). Vertical fluxes of biogenic silica in the central strait show spring and/or fall blooms, but episodic blooms occur from as early as March to as late as October (Johannessen et al. 2005b). The $\delta^{15} \mathrm{~N}$ and $\delta^{13} \mathrm{C}$ of sinking particles imply that from April to August the opaline silicate flux is produced under bloom conditions, whereas from October to February the flux is supported by slower phytoplankton growth under nutrient-replete, but presumably light-limited, 


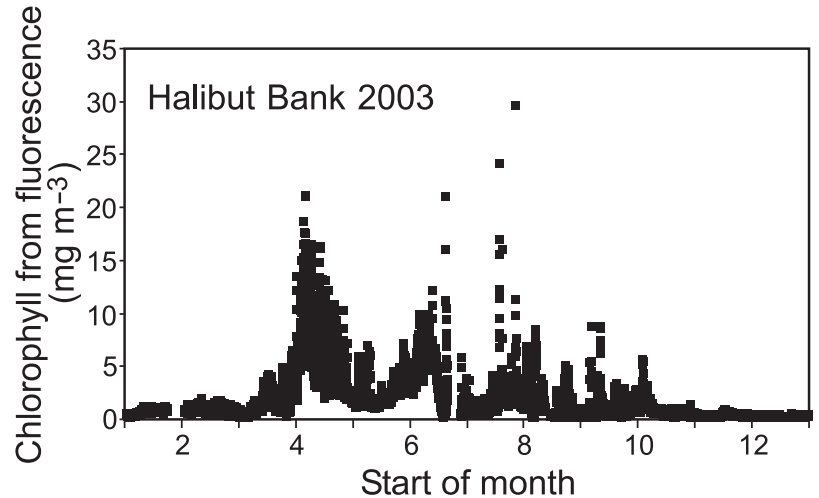

Fig. 12. Surface chlorophyll fluorescence in the south-central Strait of Georgia (Halibut Bank) in 2003 (J. Gower, IOS, DFO, unpubl. data). The spikes in chlorophyll fluorescence represent phytoplankton blooms. In 2003 the largest blooms occurred in April and June, but there is considerable interannual variability in the timing and magnitude of the blooms (A. Peña, IOS, DFO, unpubl. data)

conditions. There are no time series long enough to evaluate whether PP has changed, although it may have increased by as much as $40 \%$ over the past $25 \mathrm{yr}$ (R. Pawlowicz, University of British Columbia, pers. comm.).

Projected changes in climate appear to have little potential to alter nutrient and light conditions to effect change in PP. Annual production will remain high and be distributed over an extended period in episodic blooms. However, timing of production is sensitive to changes in timing of stability, which is primarily controlled by freshet, and secondarily, by winds. Given the projected flatter hydrograph (Fig. 4) and increase in storms, we expect blooms to begin earlier and episodic blooms to continue later into the fall. Local inputs of nutrients might lead to eutrophication in enclosed bays (Mackas \& Harrison 1997).

The composition of the phytoplankton blooms could also change, especially as the assemblage is sensitive to water temperature changes of only a few degrees (Hobson \& McQuoid 2001). Changes in assemblage may come as more frequent harmful algal blooms (HABs), with consequent toxicity to fish and shellfish. Mudie et al. (2002) suggested that observed increases in HABs during the past $50 \mathrm{yr}$ might have been caused by climate change and increased shipping. Based on Holocene records of red-tide species in a Saanich Inlet sediment core, these authors found instances of larger blooms (up to 10-fold those in modern times) in the past, and some of these blooms recurred repeatedly for centuries. However, past blooms mainly involved a single species, whereas post-industrial blooms involve a mix of species, from which these authors infer that recent HABs might be a sign of disequilibium in the marine ecosystem structure.

\subsection{Zooplankton}

Zooplankton consume phytoplankton, providing a critical transfer between PP and higher trophic levels. Zooplankton provide food for larval fish and other marine organisms, including birds (Gjerdrum et al. 2003). Zooplankton aggregate where there is food available-at fronts like those associated with the Fraser plume-which explains the long local residence time of juvenile salmon and herring (St. John et al. 1992).

The total zooplankton biomass, especially that of Neocalanus plumchrus, the dominant zooplankter in the strait, has decreased during the past $5 \mathrm{yr}$ and possibly longer (Fig. 13a). The reason for the decline is
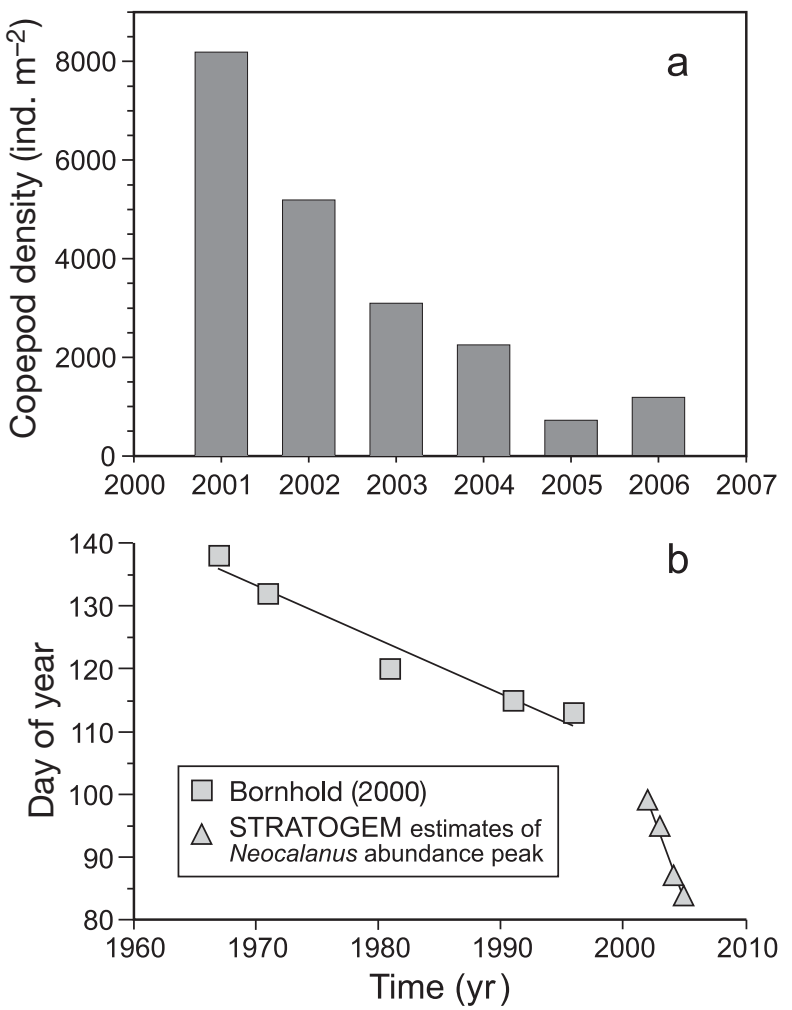

Fig. 13. (a) Recent decline in the population of Neocalanus plumchrus in the Strait of Georgia (R. El-Sabaawi and J. Dower, University of Victoria, unpubl. data; the total zooplankton population also appears to be declining). (b) A record of the timing of the peak in N. plumchrus biomass in the Strait of Georgia. Bornhold (2000) data are back-calculated, assuming that $N$. plumchrus reached its peak biomass when $50 \%$ of the population reached Stage 5. STRATOGEM data (2002 to 2005) are based on direct observations of $N$. plumchrus stage composition, assuming that peak biomass was reached when $50 \%$ of the population reached Stage 3 . The difference in the methods for determining the peak date likely explains some of the observed change. However, the peak date advanced within both data sets, and it has been suggested that the shift in $N$. plumchrus timing is accelerating (R. El-Sabaawi and J. Dower, University of Victoria, unpubl. data) 
unknown; it might be due to the advance by $\sim 2$ mo in the peak biomass of $N$. plumchrus (Fig. 13b), possibly leading to a mismatch with phytoplankton availability.

The earlier zooplankton bloom is not obviously related to phytoplankton dynamics, as these show no significant trend. Increasing water temperature might trigger earlier zooplankton blooms. Gardner (1977) showed that the populations and species assemblage of overwintering zooplankton in the strait were more strongly correlated with water temperature and stability during the preceding August/September than with conditions during the spring reproductive season. He cautioned that the physical variables might not directly cause changes in zooplankton communities, but rather be proxies for changes in chemical composition (OC, nutrients, trace metals). Since Neocalanus plumchrus spend much of their life history in deep water (Campbell \& Dower 2007), decreasing $\mathrm{O}_{2}$ and $\mathrm{pH}$ may contribute to declines. Because zooplankton react to shortterm climate variability and long-term climate change (e.g. Beaugrand et al. 2002), caution is warranted in extrapolating this $30 \mathrm{yr}$ record into the future.

A decline in zooplankton biomass, which has already been observed, or a change in the zooplankton assemblage would have ramifications for upper trophic levels that feed on zooplankton (Kitaysky \& Golubova 2000). If increasing water temperature has led to a mismatch between zooplankton and phytoplankton, then the projected temperature rise will exacerbate the mismatch. Recent work has shown that another mismatch can occur between the timing of the zooplankton biomass peak and the presence or abundance of juvenile fish and other predators (e.g. seabirds, seals, seal lions and other fish) (Yin et al. 1997, Bertram et al. 2001). Climate change may also operate on the zooplankton assemblage, replacing excellent dietary sources of energy (Neocalanus plumchrus) with less nutritious food for predators (Metridia pacifica).

\subsection{Fishes}

The sensitivity of fish species to change in the environment will depend on the specifics of their life history; accordingly, no general statement can be made regarding the vulnerability of fish to projected climate change. Rather, we must consider food sources and the ability to adapt to alternative food, critical rearing habitat, predation, including harvest by humans, sensitivity to hydrology and temperature, and many other factors. In this section we arbitrarily organize the discussion into 3 fish groups likely to face different challenges: planktivores, piscivores and anadromous fish.

Small, planktivorous fish, particularly the Pacific hake Merluccius productus and the Pacific herring Clupea pallasi, are the predominant fish species in the strait as has probably been the case throughout the Holocene (Tunnicliffe et al. 2001). Walleye pollock Theragra chalcogramma, juvenile spiny dogfish Squalus acanthias and other juvenile fish also consume zooplankton. Larger and older hake and dogfish incorporate significant proportions of fish and other prey into their diets. The biomass of planktivorous fish has been relatively stable (e.g. Saunders \& McFarlane 1999), with the exception of Pacific herring, which experienced a sudden decline from a $130 \mathrm{kt}$ peak observed in 2003 (Schweigert \& Haist 2007). There are also indications of a decline in the size at age among several of the predominant fish species, particularly hake (King \& McFarlane 2006; Fig. 14) and herring (Schweigert \& Haist 2007). Herring and other small, short-lived pelagic fishes are subject to wide fluctuations in abundance as a result of climatic and habitat changes and local productivity (Perry \& Schweigert 2008). Consequently, it is not clear whether the current decline in herring population is a short-term cycle that will soon be reversed, or whether it represents the beginning of a longer downward trend.

There have been significant changes in the populations of several predominantly piscivorous fish species in recent decades. Coho Oncorhynchus kisutch (Simpson et al. 2001; Fig. 15), Chinook salmon O. tshawytscha (Beamish et al. 1995), lingcod Ophiodon elongates (King 2005), Pacific cod Gadus macrocephalus and some inshore rockfishes (yelloweye Sebastes ruberrimus, quillback $S$. maliger, copper $S$. caurinus, black S. melanops, tiger $S$. nigrocinctus and China S. nebulosus rockfishes) have experienced declines, as reflected in landings data.

Anadromous fish like salmon occupy a special niche in west coast marine ecosystems. These iconic animals have long been important sources of food and culture to native peoples, and because their lives span such a wide geographic range, in some cases 1000s of kilometres from small natal streams to the open Pacific

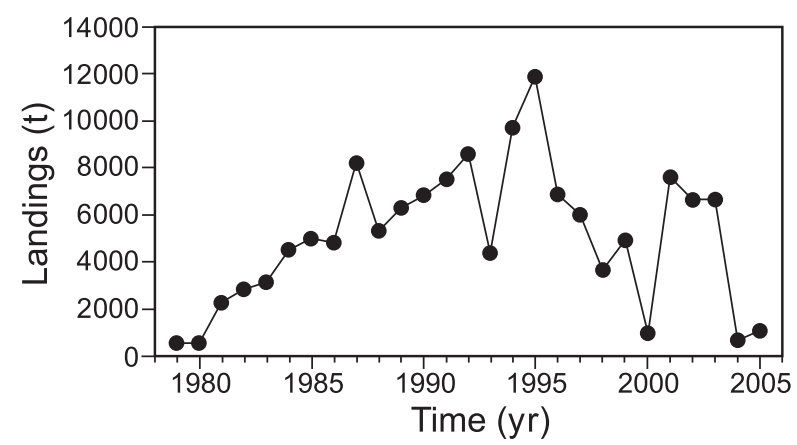

Fig. 14. Merluccius productus. Annual landings of Pacific hake captured in the Strait of Georgia (adapted from King \& McFarlane 2006) 


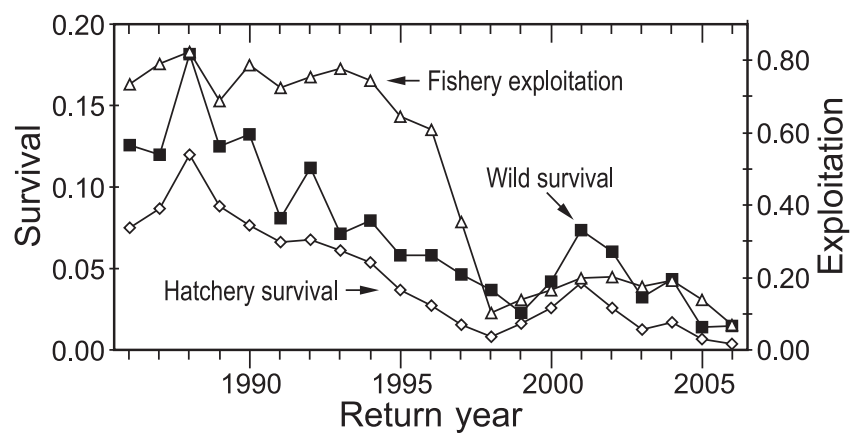

Fig. 15. Oncorhyncus kisutch. Marine coho survival (wild and hatchery) and fishery exploitation (both dimensionless) in the Georgia Basin (modified from Simpson et al. 2001)

Ocean, they are vulnerable to change in a variety of ways. During their adult lives at sea, they are susceptible to large-scale climate variation (e.g. regime shifts) that alters temperature, water-mass distribution and food supply (Mantua et al. 1997, Beamish et al. 1999). In fresh water, contamination, temperature rise and habitat destruction by logging, urbanization, hydrodevelopment and channelization have played important roles in decimating fish stocks (Slaney et al. 1996, Montgomery 2003). A water temperature of $<17^{\circ} \mathrm{C}$ is optimum for salmon migration, and at temperatures $>18^{\circ} \mathrm{C}$ fish begin to manifest stress affecting survival (Crossin et al. 2008). Above $21^{\circ} \mathrm{C}$ can be fatal.

A dramatic example of the effect of habitat destruction on fish is the series of Hell's Gate slides (19131914) associated with railroad construction, which caused catastrophic sockeye salmon Oncorhynchus nerka declines (Evenden 2004). Urbanization and habitat destruction have led to endemic decimation of west-coast salmon (Montgomery 2003, Slaney et al. 1996). An explanation for the observed decline in chinook and coho populations may be that juvenile fish entering the strait late miss the increasingly early peak in zooplankton biomass. Strait of Georgia coho are now dominated by hatchery-reared fish, which are released in late spring. Beamish et al. (2006) proposed that the effects of natural changes, e.g. earlier freshet for the Fraser River, could be mitigated by changing the timing of hatchery release. Reliance on hatchery fish must reduce the diversity of DNA in the population; whether this affects survival in the strait under changing conditions is unknown. Another explanation may relate to the trophic levels of the fish; adult chinook and coho fish, which are predominantly piscivorous, are faring more poorly than planktivores.

Chemical contaminants may play a special role with anadromous fish. These fish accumulate lipid-soluble contaminants (e.g. PCB, DDT) and focus them into their natal streams, where they have the potential to produce toxic effects on the fish themselves and on other ecosystem components (Blais et al. 2007). A curious disruption in the timing of sockeye Fraser migrations that led to large-scale, pre-spawning mortality in the late 1990s to early 2000s might also have been a consequence of contaminants operating together with climate (Couillard et al. 2008).

Fish face multiple threats from global and local stressors. Global climate change may alter food availability in the open ocean and thus affect survival at sea (e.g. Mantua et al. 1997). Observed declines in $\mathrm{O}_{2}$ in basin waters may affect the distributions of resident fish depending on their tolerances; Atlantic cod Gadus morhua, for example, show significant metabolic effects at $<70 \% \mathrm{O}_{2}$ saturation $\left(4.7 \mathrm{ml} \mathrm{l}^{-1}\right)$ and a lethal threshold at $20 \%$ saturation $\left(1.3 \mathrm{ml} \mathrm{l}^{-1}\right.$ ) (Chabot \& Claireaux 2008). Climate change can also alter the timing and quality of zooplankton production within the strait, affecting outmigrating and resident fish. Temperature and flow regimes in rivers and lakes provide tipping points beyond which anadromous fish stocks will be extirpated. Increased seawater temperature can also favour invasive species and parasites, such as sea lice Lepeophtheirus salmonis that survive better and mature more quickly under warmer conditions. Local stressors, including fishing, habitat destruction and contamination, have historically been linked to the most obvious impacts on fish. These stressors also offer the greatest potential to be managed by local action.

\subsection{Benthos}

In recent reviews of benthic environments of the Strait of Georgia, Burd et al. (2008a,b) conclude that abundance and biomass of subtidal benthos depend mostly on the flux of labile OC to sediments. While numbers of most species decline with water depth, the percent contribution by polychaetes increases with depth at the expense of bivalves. In particular, bivalves are important above a water depth of $100 \mathrm{~m}$, but are severely impoverished in the deeper basin sediments. For shallow habitats, bottom characteristics and the supply of organic matter have been found to be important (Levings et al. 1983). Recent acquisitions of multibeam bathymetry (Barrie et al. 2005) confirm discrete grab samples, indicating patchy benthic sediment characteristics.

It is important to note that human activities have already drastically altered many shallow benthic environments (Levings \& Thom 1994), but no assessment of temporal trends in benthic abundance or assemblage has been carried out. In the future, SLR and increased storm activity will affect the nearshore, likely in tandem with human activities, to mitigate the effects of these changes on nearshore structures. Basin benthos 
will be sensitive to changes in OC flux (Burd et al. 2008a), DO (Fig. 16), pH, contaminants and habitat destruction. Ongoing urbanization will continue to disrupt nearshore habitats through dredging, port construction, shipping and outfalls. Physical disruption can also have significant consequences for deep-water benthic environments (Robinson \& Frid 2008). In the Strait of Georgia, bottom trawling is implicated in the observed destruction of perhaps half of the siliceous sponge reefs (Cook et al. 2008). Sedimentary contaminants (Fig. 8) may be taken up by benthic foragers, which has led in the past to fisheries closures for crab, shrimp and bivalves.

\subsection{Marine mammals}

Marine mammals, at the top of the food web, are at risk both from the perspective of competition with humans for food and of exposure to biomagnifying contaminants. The population of resident harbour seals Phoca vitulina has grown and stabilized over the past few decades (Fig. 17a), likely because humans stopped hunting them (Olesiuk 1999). In contrast, northern and southern resident killer whales Orcinus orca, which were stable or increasing before the 1990s, are now declining (Fig. 17b; Ford et al. 2005). Three factors are likely involved in the decline: availability of prey, exposure to contaminants and disturbance by marine traffic (Ross 2006, DFO 2008). The southern resident killer whales are dependent almost entirely on Chinook salmon, even though other salmon are often more abundant (DFO 2008). The whales may not be able to adjust to recent declines in Chinook populations. In the

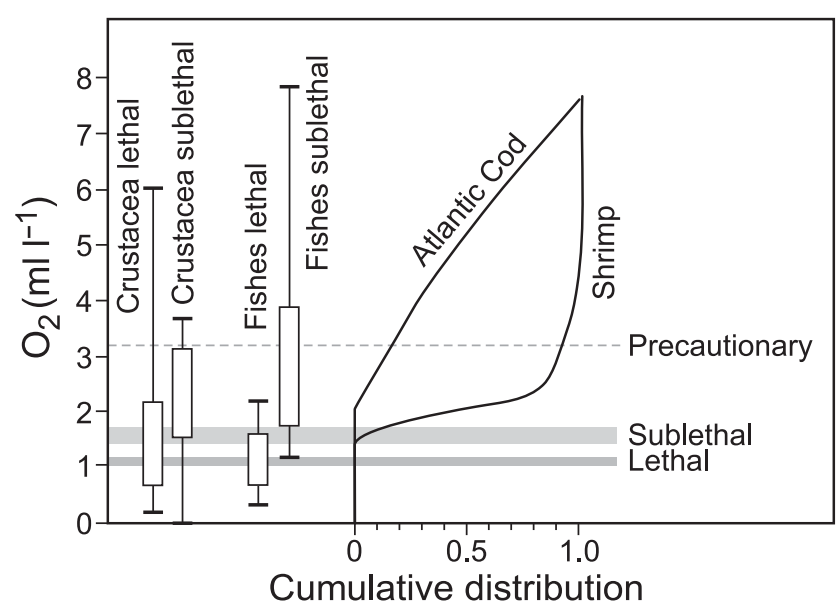

Fig. 16. Sensitivity of various species to declining $\mathrm{O}_{2}$ levels. On the left, ranges of lethality and sublethality based on an extensive review are given for Crustacea and fish (adapted from Vaquer-Sunyer \& Duarte 2008). On the right, the effect of $\mathrm{O}_{2}$ levels in the Gulf of St. Lawrence is shown in the distributions of fish and shrimp (adapted from Gilbert et al. 2007)
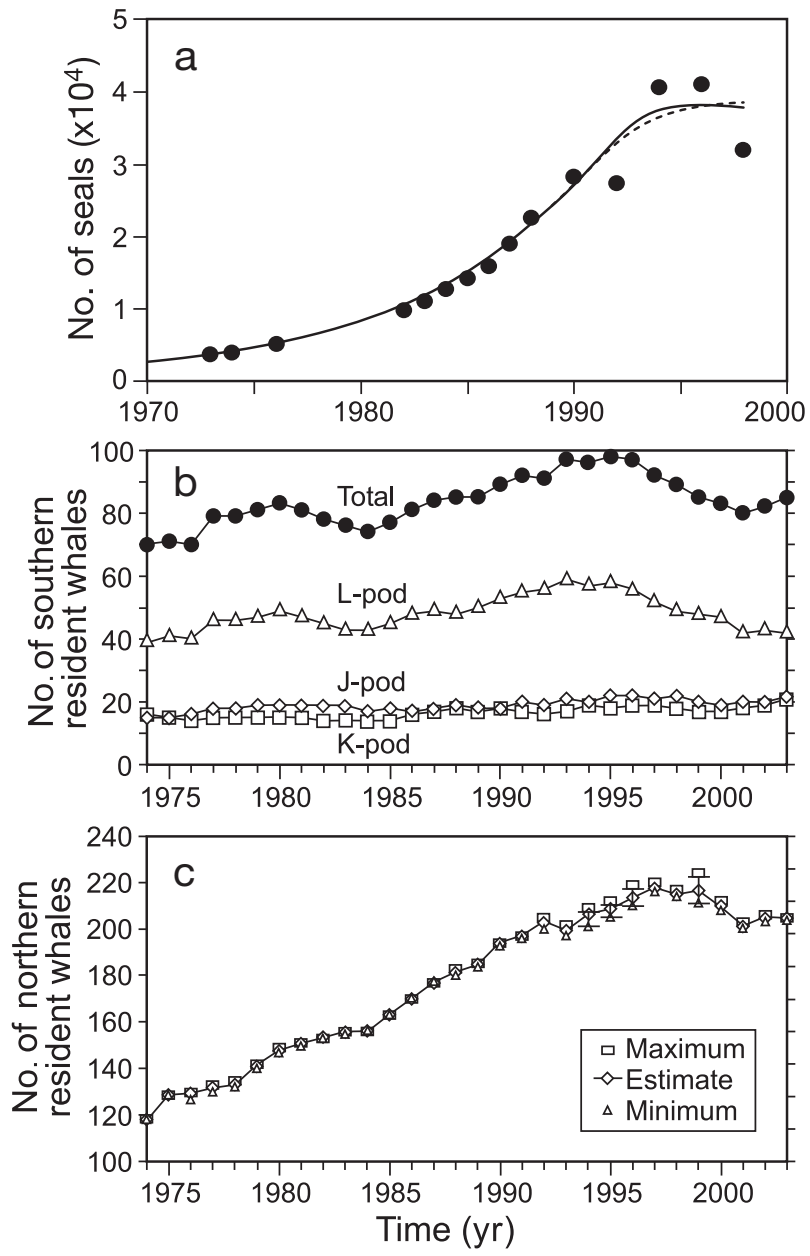

Fig. 17. (a) Population of harbour seals Phoca vitulina in the Strait of Georgia. The seal population increased from the 1970 s to the mid-1990s, after the cessation of hunting and has since stabilized (Olesiuk 1999). The dotted and solid lines represent 2 different model fits to the data. $(b, c)$ Population size and trends for (b) southern and (c) northern resident killer whales Orcinus orca from 1974 to 2003 (adapted from DFO 2008)

case of organochlorines like PCBs and PBDEs, local killer whales are among the most contaminated marine mammals in the world (Ross et al. 2000, Grant \& Ross 2002). Killer whales are susceptible to contaminant accumulation, because they maintain burdens within their population over decades (Hickie et al. 2007). Grey whales Eschrichtius robustus, which feed at a much lower trophic level than killer whales, nevertheless accumulate high contaminant concentrations from plankton and sediments (Ross et al. 2007). It seems likely that contaminant burdens, which are sufficient to trigger effects such as immunotoxicity for harbour seals, would similarly threaten whales. Local harbour seals are also highly contaminated with PCBs, dioxins and furans from local and long-range sources (Ross et al. 2004). 
Killer whales appear especially vulnerable, as their populations are already small and declining, and they are threatened by nutritional stress, contaminants and marine traffic. Although seals have recovered from widespread hunting, their high contaminant burdens may leave them vulnerable to disease (Ross et al. 1996). Climate variability and change can alter the exposure of resident animals to viruses brought by migratory carriers (Dietz et al. 1989), or they can alter the availability of prey and thereby increase their exposure to contaminants, either through dietary pathways or through burning down fat reserves (Couillard et al. 2008).

\subsection{Birds}

Marine birds (shorebirds, seabirds and seaducks) are highly visible, and, in principle, it is easier to observe declines in their populations, which make these species important indicators of environmental stress (Morton 2009). However, bird populations are also subject to natural fluctuations, which complicate the interpretation of trends over short time periods. Shorebirds, such as sandpipers Calidris sp. and plovers Charadrius sp., typically exploit the interface between land and water, foraging principally on intertidal invertebrates found on the surface or within substrates (Cramp \& Simmons 1983). They may migrate widely from breeding areas in the Arctic to spend winter months in tropical and subtropical ecosystems. Shorebirds stop along the way and refuel for the next leg of their journey. Migration is one of the riskiest phases of the shorebirds' annual cycle (Hockey et al. 1998, Lank et al. 2003), and food availability during migration is critical, not only to offset the metabolic costs of sustained flight, but to reduce exposure to predation while refuelling (Lank et al. 2003).

Many shorebird species are declining globally (O'Hara et al. 2007). Widespread degradation and habitat loss at stopover sites and on overwintering grounds may be the cause of these population declines; however, this has not been clearly shown for most shorebird species (Sherry \& Holmes 1996). Shorebird species generally express a high degree of fidelity to breeding, stop-over and wintering locations (Summers et al. 1990, Butler et al. 2002), so they cannot readily adapt to degradation of critical habitat by moving elsewhere. The mudflats associated with the Fraser River delta provide a crucial stop-over point for many species of shorebirds, and a number of migratory pathways probably converge there (Butler et al. 1996). Urbanization of the shoreline threatens these birds, as does the potential loss of intertidal areas due to projected SLR.
Seabirds, such as alcids, cormorants Phalacrocorax sp. and albatrosses Diomedea sp., spend most of their lives at sea, but come ashore to breed, typically in colonies on islands (Harrison 1987). Marbled murrelets Brachyramphus marmoratus are unique among the seabird species, in that they breed in trees, particularly in old-growth forests (Nelson 1997), which are increasingly rare in coastal British Columbia.

Seabirds are also sensitive to variations in the timing and magnitude of zooplankton biomass. Peak food requirements during chick rearing generally coincide with peak productivity in local plankton. A mismatch in timing or reduced productivity can lead to reproductive failure (Gjerdrum et al. 2003). If the zooplankton biomass in the Strait of Georgia continues to peak earlier in the year and the sea birds do not adapt, the birds will face reproductive failure.

Sea ducks spend much of their lives at sea, but tend to stay close to shore. They typically breed inland around lakes, rivers and marshes (Cramp \& Simmons 1983), making them vulnerable to degradation of habitat in breeding and wintering areas. All marine birds are sensitive to oil slicks, and top predatory birds that feed out of aquatic systems are especially vulnerable to contaminants through biomagnification (Elliott et al. 2000).

Birds are likely to experience serious population crashes due to loss of habitat (e.g. wetlands, staging areas, shoreline alteration due to SLR and development, harvesting of old-growth forest) and changes in the timing of zooplankton availability. For migratory birds, pressure on local populations may be delivered by human activities (hunting, development, pesticides) elsewhere.

\section{CONCLUSIONS}

\subsection{Risks to biota}

Coastal ecosystems have adapted to large-scale climate change in the past, including SLR and ice ages. Now, these systems are being threatened by unprecedented stresses related to human activities. These stresses include rapid climate change, habitat destruction and encroachment by humans, exposure to contaminants, and extraction of fish and shellfish for human consumption. The adaptability of plants and animals to these changes is unknown, and we know far too little about plasticity or resilience, which vary widely among species. We summarize below what we see as the most pressing risks to biota (Fig. 18).

Dissolved $\mathrm{O}_{2}$ and $\mathrm{pH}$ in deep basin water of the strait will be affected by composition of upwelled coastal water and by internal loadings of nutrients and organic carbon. Bottom water already approaches hypoxic 


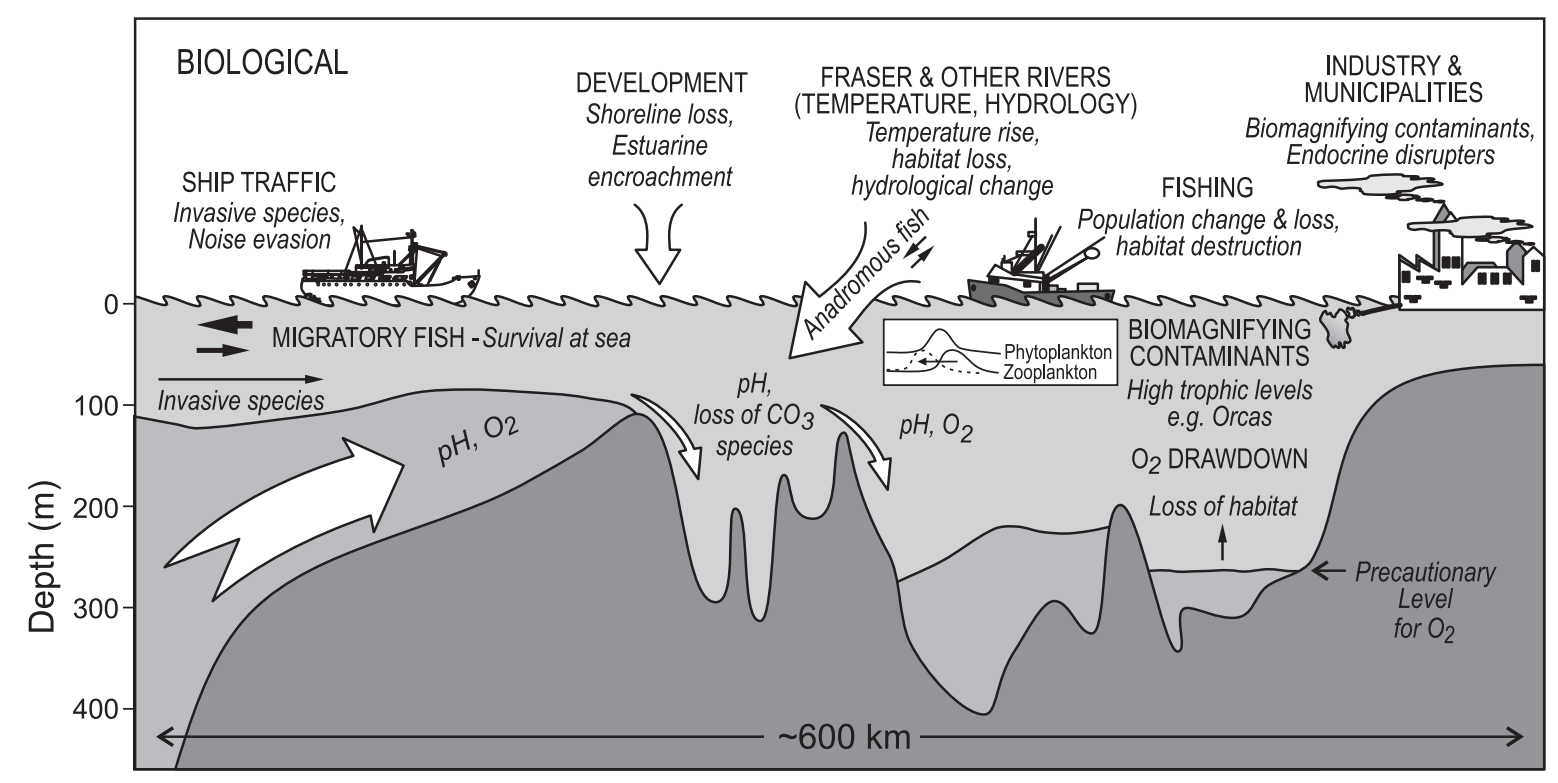

Fig. 18. Schematic diagram showing the system factors (in capitals) that are most likely to lead to impacts on biota (in italic) in the Strait of Georgia. Basin water decreases in $\mathrm{O}_{2}$ and/or $\mathrm{pH}$ will displace or extinguish benthic biota. Changes in coupling between phytoplankton and zooplankton grazers (inset) will alter the food web structure. Changes in flow and temperature regimes together with changes in survival at sea will affect migratory fish. Alteration in contaminant inputs will especially affect high trophic levels where biomagnification comes into play. Habitat destruction or alteration will lead to changes in the way sea level rise and storms interact with shores

thresholds; further $\mathrm{O}_{2}$ depletion in replacement water and/or increase in labile organic flux to basin waters would displace mobile animals from the habitat and extirpate sessile benthos. Nothing is known about the role that $\mathrm{pH}$ plays presently in basin waters, but declining $\mathrm{pH}$ could interact with oxygen depletion to stress animals further. Both $\mathrm{O}_{2}$ and $\mathrm{pH}$ should be monitored in basin waters.

Change in the timing of zooplankton blooms, possibly forced by temperature increase, would change connectivity in the food web among phytoplankton, zooplankton, fish and birds. Neither the cause nor the consequence of the observed change in is well understood, but low trophic-level changes have cascaded into higher trophic levels in the Bering Sea (Kitaysky \& Golubova 2000). Birds in the Strait of Georgia may already be stressed by such timing changes.

Increasing temperature and decreased flow in rivers threaten the survival of anadromous fish. A model predicts that by the end of this century, the number of days when the temperature of the Fraser River exceeds $20^{\circ} \mathrm{C}$ will have increased 10 -fold (Morrison et al. 2002), and this threshold may be exceeded in other rivers as well. This prediction is within $1^{\circ} \mathrm{C}$ of the temperature prohibitive to salmon.

Contaminants threaten higher trophic level organisms, such as killer whales and seals. New chemicals like pharmaceuticals and plastics appear to pose the greatest threat of harm in the future.
Invasive species are a sign of a stressed ecosystem. Many factors contribute to successful invasion, including a climate change that favours the invader and vectors, like ballast water, that promote the arrival of the invader. Eelgrass beds, aquaculture and native clams and crabs are all potentially at risk.

Shorelines are threatened by SLR, increased storms and development. Past transgressions of the sea over land have resulted in readjustment of intertidal zones, beaches and mudflats. Transgressions now face seawalls and dykes, which prevent inland migration of mudflats and intertidal zones, therefore leading to loss of critical habitat.

Excessive fishing decreases populations, but, provided they are not pushed past critical thresholds, fish populations recover when pressure is reduced. All coastal regions, including the Strait of Georgia, have seen declines and population threats due to overharvest, bycatch and mechanical damage due to bottom trawling.

None of the above stresses acts in isolation, and most biota will face more than one. Salmon, killer whales and seabirds are especially subject to multiple stresses. Salmon rely on a wide range of habitats, from spawning to adult growth. Harvesting by humans, and survival at sea (which is affected by large-scale climate change and regime shifts) (Mantua et al. 1997), interact with habitat destruction, contamination, rise in river temperature and decrease in river flow. Killer 
whales face declines in Chinook, high exposure to contaminants and traffic. The population of resident killer whales has recently declined to the point that northern residents are threatened and southern residents are endangered (DFO 2008). Even if local sources of contaminants are eliminated, long-lived killer whales will continue to carry contaminant burdens for decades (Hickie et al. 2007, Ross et al. 2007), which adds urgency to controlling persistent chemicals. Seabirds are highly vulnerable to habitat destruction, oiling at sea, contaminants and marine plastics. They are also vulnerable to change in food supply, which can be an advantage to the birds that adapt and a disadvantage to those that cannot (Kitaysky \& Golubova 2000). As highly visible animals, seabirds provide sentinels of change (Morton in 2009).

\subsection{Human actions}

When biota face multiple stressors, reducing one or more of the stresses may enhance resistance to the remainder (Brander 2008). Local management has the potential to control coastal development and other forms of habitat destruction, input of local contaminants including nutrients and organics, fishing pressure and, in some cases, river temperature and flow.

Coastal development can be controlled locally and, with a projected SLR of $0.6 \mathrm{~m}$ or more by 2100 , humans will have to respond to threats to property. Clearly, decision-makers could limit further development in the path of harm (IPCC 2007c), but responses that would preserve critical intertidal habitat are also needed. Certain benthic areas, like sponge reefs, are being physically damaged Cook et al. (2008). Small incremental losses that together spell the demise of critical habitat can only be prevented through cooperative, basin-wide management.

Contaminants enter the Georgia Basin from global and local sources. The control of globally distributed contaminants (e.g. DDT, PCBs) must be addressed through international agreements, for which there has been considerable success (Stockholm Convention 2001). Effort to control the release of contaminants locally needs to be informed by an understanding of the sources (global and local), sinks and pathways of contaminants in the receiving environment and of which contaminants pose the greatest threats (Chapman et al. 2008). Source control, if practicable, is clearly the best solution, particularly for persistent contaminants (Ross et al. 2009).

Fisheries management provides one of the most direct ways to control stress on populations. Government action to subsidize continued resource extraction when it is not profitable has been proposed to play a final role in the demise of some resources (Ludwig et al. 1993). Populations of some of the fishes in the Strait of Georgia, particularly piscivorous fish, are declining for reasons that are not fully understood. Because fish face so many threats, it is difficult to assign a single cause to population decline. More positively, multiple stresses offer multiple options to reduce stress. Reducing fishing pressure, according to Brander (2008), maximizes sustainable yields, allows fish and marine ecosystems to adapt to climate impacts and helps to reduce greenhouse gas emissions. However, left too long without action, a critical species may move beyond recovery (e.g. Atlantic cod; Hutchings 2005), which underscores the urgency of timely action.

Acknowledgements. The authors thank B. McCarter and P. O'Hara for providing information and insight into the status and sensitivity of fish and birds in the Strait of Georgia. We thank D. Masson, R. El-Sabaawi, J. Dower, J. Morrison and J. Gower for providing and interpreting figures from their work. P. Kimber prepared the figures. We are grateful to G. Gillespie, M. Galbraith, J. Irvine, D. Johannessen, D. Mackas, S. McFarlane, P. Olesiuk, A. Peña, P. Ross and J. Schweigert for discussing or reviewing sections of the work, and to Ken Denman and 2 anonymous reviewers who guided us to a more readable paper.

\section{LITERATURE CITED}

Alverson DL, Freeberg MH, Murawski SA, Pope JG (1994) A global assessment of fisheries bycatch and discards. FAO Fisheries Technical Paper 339, FAO, Rome

Anderson CN, Hseih CH, Sandin SA, Hewitt R and others (2008) Why fishing magnifies fluctuations in fish abundance. Nature 452:835-839

Andrews JE, Burgess D, Cave RR, Coombes EG, Jickells TD, Parkes DJ, Turner RK (2006) Biogeochemical value of managed realignment, Humber estuary, UK. Sci Total Environ 371:19-30

> Barnett TP, Adam JC, Lettenmaier DP (2005) Potential impacts of a warming climate on water availability in snow-dominated regions. Nature 438:303-309

Barrie JV, Hill PR, Conway KW, Iwanowska K, Picard K (2005) Environmental Marine Geoscience 4: Georgia Basin: seabed features and marine geohazards. Geoscience Canada 32:145-156

Beamish RJ, Riddell BE, Neville CEM, Thomson BL, Zhang Z (1995) Declines in Chinook salmon catches in the Strait of Georgia in relation to shifts in marine environment. Fish Oceanogr 4:243-256

Beamish RJ, Noakes DJ, McFarlane GA, Klyashtorin L, Ivanov VV, Kurashov V (1999) The regime concept and natural trends in the production of salmon. Can J Fish Aquat Sci 56:516-526

Beamish RJ, Sweeting RM, Neville CM, Lange KT (2006) Declining marine survival of Coho and associated behavioural changes 2006. Proceedings of the ASLO Summer Meeting, Victoria, British Columbia, Canada, June 4-9

Beaugrand G, Reid PC, Ibañez F, Lindley JA, Edwards M (2002) Reorganization of North Atlantic marine copepod biodiversity and climate. Science 296:1692-1694 
Bertram DF, Mackas DL, McKinnell SM (2001) The seasonal cycle revisited: interannual variations and ecosystem consequences. Prog Oceanogr 49:283-307

Blais JM, Macdonald RW, Mackay D, Webster E, Harvey C, Smol JP (2007) Biologically mediated transport of contaminants to aquatic systems. Environ Sci Technol 41: 1075-1084

Bornhold B (2000) Interannual and interdecadal patterns in timing and abundance of phytoplankton and zooplankton in the central Strait of Georgia, BC: with special reference to Neocalanus plumchrus. PhD, University of British Columbia, Vancouver

Brander K (2008) Tackling the old familiar problems of pollution, habitat alteration and overfishing will help with adapting to climate change. Mar Pollut Bull 56:1957-1958

> Buddemeier RW, Smith SV, Swaney DP, Crossland CJ, Maxwell BA (2008) Coastal typology: an integrative 'neutral' technique for coastal zone characterization and analysis. Estuar Coast Shelf Sci 77:197-205

Burd BJ, Macdonald RW, Johannessen SC, van Roodselaar A (2008a) Responses of subtidal benthos of the Strait of Georgia to ambient sediment conditions and natural and anthropogenic depositions. Mar Environ Res 66:S62-S69

Burd BJ, Barnes PAG, Wright CA, Thomson RE (2008b) A review of subtidal benthic habitats and invertebrate biota of the Strait of Georgia, British Columbia. Mar Environ Res 66:S3-S38

Butler RW, Delgado FD, de La Cueva H, Pulido V, Sandercock BK (1996) Site fidelity and local movements of migrating western sandpipers on the Fraser River estuary. Wilson Bull 114:662-672

Butler RW, Shepherd PCF, Lemon MJF (2002) Site fidelity and local movements of migrating western sandpipers on the Fraser River estuary. Wilson Bull 114:485-490

Campbell RW, Dower JF (2007) Depth distribution during the life history of Neocalanus plumchrus in the Strait of Georgia. J Plankton Res 30:7-20

Chabot D, Claireaux G (2008) Environmental hypoxia as a metabolic constraint on fish: the case of Atlantic cod, Gadus morhua. Mar Pollut Bull 57:287-294

> Chapman PM, Cullen J, Garrett C, Littlepage J and others (2008) Sewage treatment wasted-the Victoria (BC, Canada) example. Mar Pollut Bull 56:1815-1816

Cook SE, Conway K, Burd B (2008) Status of the glass sponge reefs in the Georgia Basin. Mar Environ Res 66:80-86

> Couillard CM, Macdonald RW, Courtenay SC, Palace VP (2008) Interactions between toxic chemicals and other environmental factors affecting the risk of impacts on aquatic organisms: a review with a Canadian perspective-interactions affecting exposure. Environ Rev 16:1-17

Cramp S, Simmons KEL (1983) The birds of the western Palearctic, Vol 3. Oxford University Press, Oxford

> Crossin GT, Hinch SG, Cooke SJ, Welch DW and others (2008) Exposure to high temperature influences the behaviour, physiology, and survival of sockeye salmon during spawning migration. Can J Zool 86:127-140

DFO (Fisheries and Oceans Canada) (2007) State of the Pacific Ocean 2006. Report No. 2007/001, Government of Canada, Fisheries and Oceans Canada, Sidney

DFO (2008) Recovery strategy for the northern and southern resident killer whales (Orcinus orca) in Canada, Species at Risk Act: recovery strategy series. DFO, Ottawa

> Dietz R, Ansen CT, Have P (1989) Clue to seal epizootic. Nature 338:627

> Doney SC, Fabry VJ, Feely RA, Kleypas JA (2009) Ocean acidification: the other $\mathrm{CO}_{2}$ problem. Ann Rev Mar Sci 1: 169-192
Elliott JE, Machmer MM, Wilson LK, Henny CJ (2000) Contaminants in ospreys from the Pacific Northwest. II. Organochlorine pesticides, polychlorinated biphenyls and mercury, 1991-1997. Arch Environ Contam Toxicol 38: 93-106

Evenden M (2004) Social and environmental change at Hells Gate, British Columbia. J Hist Geogr 30:130-153

Fabry VJ, Seibel BA, Feely RA, Orr JC (2008) Impacts of ocean acidification on marine fauna and ecosystem processes. ICES J Mar Sci 65:414-432

Feely RA, Sabine CL, Hernandez-Ayon JM, Ianson D, Hales B (2008) Evidence for upwelling of corrosive 'acidified' water onto the continental shelf. Science 320:1490-1492

Ford JKB, Ellis GM, Olesiuk P (2005) Linking prey and population dynamics: Did food limitation cause recent declines of 'resident' killer whales (Orcinus orca) in British Columbia? Report No. 2005/042, Fisheries and Oceans Canada, Nanaimo

Gardner GA (1977) Analysis of zooplankton population fluctuations in the Strait of Georgia, British Columbia. J Fish Res Board Can 34:1196-1206

Gilbert D, Chabot D, Archembault P, Rondeau B, Hébert S (2007) Appauvrissement en oxygène dans les eaux profondes du Saint-Laurent marin: causes possibles et impacts écologiques. Nat Can 131:67-75

Gillespie GE (2007) Distribution of intertidal non-indigenous species on the Pacific Coast of Canada. Nippon Suisan Gakkai Shi 73:1133-1137

Gjerdrum C, Valle AMJ, St. Clair CC, Bertram DF, Ryder JL, Blackburn GS (2003) Tufted puffin reproduction reveals ocean climate variability. Proc Natl Acad Sci USA 100: 9377-9382

Grant SCH, Ross PS (2002) Southern resident killer whales at risk: toxic chemicals in the British Columbia and Washington environment. Can Tech Rep Fish Aquat Sci 2412

Hall-Spencer JM, Rodolfo-Metalpa R, Martin S, Ransome E and others (2008) Volcanic carbon dioxide vents show ecosystem effects of ocean acidification. Nature 454:96-99

> Hansen J, Sato M, Kharecha P, Russell G, Lea DW, Siddall M (2007) Climate change and trace gases. Philos Trans R Soc Lond A 365:1925-1954

Harrison PJ (1987) Seabirds of the world: a photographic guide. Princeton University Press, Princeton

Harrison PJ, Fulton JD, Taylor FJR, Parsons TR (1983) Review of the biological oceanography of the Strait of Georgia: pelagic environment. Can J Fish Aquat Sci 40:1064-1094

> Heath DD, Rawson PD, Hilbish TJ (1995) PCR-based nuclear markers identify alien blue mussel (Mytilus sp.) genotypes on the west coast of Canada. Can J Fish Aquat Sci 52: 2621-2627

Hester KC, Peltzer ET, Kirkwood WJ, Brewer PG (2008) Unanticipated consequences of ocean acidification: a noisier ocean at lower pH. Geophys Res Lett 35:L19601, doi: 10.1029/2008GL034913

> Hobson LA, McQuoid MR (2001) Pelagic diatom assemblages are good indicators of mixed water intrusions into Saanich Inlet, a stratified fjord in Vancouver Island. Mar Geol 174: $125-138$

> Hickie BE, Ross PS, Macdonald RW, Ford JKB (2007) Killer whales (Orcinus orca) face protracted health risks associated with lifetime exposure to PCBs. Environ Sci Technol 41:6613-6619

Hill PR, Conway K, Lintern DG, Meulé S, Picard K, Barrie JV (2008) Sedimentary processes and sediment dispersal in the southern Strait of Georgia, BC, Canada. Mar Environ Res 66:S39-S48

Hirsch R, Ternes T, Haberer K, Kratz KL (1999) Occurrence of 
antibiotics in the aquatic environment. Sci Total Environ 225:109-118

Hockey PAR, Turpie JK, Velásquez CR (1998) What selective pressures have driven the evolution of deferred northward migration by juvenile waders? J Avian Biol 29:325-330

Hutchings JA (2005) Life history consequences of overexploitation to population recovery in Northwest Atlantic cod (Gadus morhua). Can J Fish Aquat Sci 62:824-832

IPCC (Intergovernmental Panel on Climate Change) (2007a) Summary for policymakers. In: Solomon S, Quinn D, Manning M, Chen Z and others (eds) Climate change 2007: the physical science basis. Contribution of Working Group I to the 4th assessment report of the Intergovernmental Panel on Climate Change. Cambridge University Press, Cambridge

IPCC (2007b) Climate change 2007: the physical science basis. Contribution of Working Group I to the 4th assessment report of the Intergovernmental Panel on Climate Change. Cambridge University Press, Cambridge

IPCC (2007c) Climate change 2007: impacts, adaptation and vulnerability. Contribution of Working Group II to the 4th assessment report of the Intergovernmental Panel on Climate Change. Cambridge University Press, Cambridge

Jackson JBC (2008) Ecological extinction and evolution in the brave new ocean. Proc Natl Acad Sci USA 105:11458-11465

Jakob M, McKendry I, Lee R (2003) Long-term changes in rainfall intensities in Vancouver, British Columbia. Can Water Resour J 28:587-604

Johannessen SC, Macdonald RW, Paton DW (2003) A sediment and organic carbon budget for the greater Strait of Georgia. Estuar Coast Shelf Sci 56:845-860

- Johannessen SC, Macdonald RW, Eek MK (2005a) Historical trends in mercury sedimentation and mixing in the Strait of Georgia, Canada. Environ Sci Technol 39:4361-4368

Johannessen SC, O'Brien MC, Denman KL, Macdonald RW (2005b) Seasonal and spatial variations in the source and transport of sinking particles in the Strait of Georgia, British Columbia, Canada. Mar Geol 216:59-77

> Johannessen SC, Masson D, Macdonald RW (2006) Distribution and cycling of suspended particles inferred from transmissivity in the Strait of Georgia, Haro Strait and Juan de Fuca Strait. Atmos-Ocean 44:17-27

Johannessen SC, Macdonald RW, Wright CA, Burd B, Shaw DP, van Roodselaar A (2008a) Joined by geochemistry, divided by history: PCBs and PBDEs in Strait of Georgia sediments. Mar Environ Res 66:S112-S120

Johannessen SC, Potentier G, Wright CA, Masson D, Macdonald RW (2008b) Water column organic carbon in a Pacific marginal sea (Strait of Georgia, Canada). Mar Environ Res 66:S49-S61

King JR (2005) Strait of Georgia lingcod (Ophiodon elongatus) assessment and advice for fishery management. CSAS Science Advisory Report No. 2005/042, Government of Canada, Fisheries and Oceans Canada, Nanaimo

King JR, McFarlane GA (2006) Shift in the size-at-age of the Strait of Georgia population of Pacific hake (Merluccius productus). CCOFI Rep 47:111-118

Kitaysky AS, Golubova EG (2000) Climate change causes contrasting trends in reproductive performance of planktivorous and piscivorous alcids. J Anim Ecol 69:248-262

Knutzen J (1981) Effects of decreased pH on marine organisms. Mar Pollut Bull 12:25-29

Lank D, Butler R, Ireland J, Ydenberg R (2003) Effects of predation danger on migration strategies of sandpipers. Oikos 103:303-319

Levings CD, Thom RM (1994) Habitat changes in Georgia Basin: implications for resource management and restora- tion. Can Tech Rep Fish Aquat Sci 1948:330-351

Levings CD, Foreman RE, Tunnicliffe VJ (1983) Review of benthos of the Strait of Georgia and contiguous fjords. Can J Fish Aquat Sci 40:1120-1141

Levings CD, Kieser D, Jamieson GS, Dudas S (2002) Marine and estuarine alien species in the Strait of Georgia, British Columbia. In: Caludi R, Nantel P, Muckel-Jeffs E (eds) Alien invaders in Canada's waters, wetlands, and forests. Natural Resources Canada, Canadian Forestry Service, Ottawa, Ontario, p 111-131

Levings CD, Cordell JR, Ong S, Piercey GE (2004) The origin and identity of invertebrate organisms being transported to Canada's Pacific coast by ballast water. Can J Fish Aquat Sci 61:1-11

Ludwig D, Hilborn R, Walters C (1993) Uncertainty, resource exploitation, and conservation: lessons from history. Science 260:17-36

> Macdonald RW, Macdonald DM, O'Brien MO, Gobeil C (1991) Accumulation of heavy metals $(\mathrm{Pb}, \mathrm{Zn}, \mathrm{Cu}, \mathrm{Cd})$, carbon and nitrogen in sediments from Strait of Georgia, B.C., Canada. Mar Chem 34:109-135

> Macdonald RW, Cretney WJ, Crewe N, Paton D (1992) A history of octachlordibenzo- $p$-dioxin, 2,3,7,8-tetrachlorodibenzofuran, and 3,3',4,4'-tetrachlorobiphenyl contamination in Howe Sound, British Columbia. Environ Sci Technol 26:1544-1550

> Mackas DL, Harrison PJ (1997) Nitrogenous nutrient sources and sinks in the Juan de Fuca Strait / Strait of Georgia / Puget Sound estuarine system: assessing the potential for eutrophication. Estuar Coast Shelf Sci 44:1-21

> Mantua NJ, Hare SR, Zhang Y, Wallace JM, Francis RC (1997) A Pacific interdecadal climate oscillation with impacts on salmon production. Bull Am Meteorol Soc 78:1069-1079

Masson D (2002) Deep water renewal in the Strait of Georgia. Estuar Coast Shelf Sci 54:115-126

Masson D (2006) Seasonal water mass analysis for the Straits of Juan de Fuca and Georgia. Atmos-Ocean 44:1-15

> Masson D, Cummins PF (2000) Fortnightly modulation of the estuarine circulation in Juan de Fuca Strait. J Mar Res 58:439-463

> Masson D, Cummins PF (2007) Temperature trends and interannual variability in the Strait of Georgia, British Columbia. Cont Shelf Res 27:634-649

MOE (Ministry of the Environment) (2006) British Columbia Coast and Marine Environment Project 2006: population and economic activity. Ministry of the Environment, Vancouver. Available at: www.env.gov.bc.ca/soe/bcce/01_ population_economic/marine_traffic.html

Montgomery DR (2003) King of fish: the thousand year run of salmon. Westview Press, Oxford

Moore CJ (2008) Synthetic polymers in the marine environment: a rapidly increasing, long-term threat. Environ Res 108:131-139

> Morrison J, Quick MC, Foreman MGG (2002) Climate change in the Fraser River watershed: flow and temperature projections. J Hydrol (Amst) 263:230-244

Morton B (2009) Let's hear it for the birdwatchers! Mar Pollut Bull 58:1-2

> Mudie PJ, Rochon A, Levac E (2002) Palynological records of red tide-producing species in Canada: past trends and implications for the future. Palaeogeogr Palaeoclimatol Palaeoecol 180:159-186

Muir DCG, Howard PH (2006) Are there other persistent organic pollutants? A challenge for environmental chemists. Environ Sci Technol 40:7157-7166

> Myers RA, Worm B (2003) Rapid worldwide depletion of predatory fish communities. Nature 423:280-283 
Nelson KS (1997) Marbled murrelet (Brachyramphus marmoratus). Cornell Lab of Ornithology, Ithaca

O'Hara PD, Haase BJM, Elner RW, Smith BD, Kenyon JK (2007) Are population dynamics of shorebirds affected by El Niño/Southern Oscillation (ENSO) while on their nonbreeding grounds in Ecuador? Estuar Coast Shelf Sci 74: 96-108

Occhipinti-Ambrogi A (2007) Global change and marine communities: alien species and climate change. Mar Pollut Bull 55:342-352

Olesiuk P (1999) An assessment of the status of harbour seals (Phoca vitulina) in British Columbia. Report No. 99/33, Canadian Stock Assessment Secretariat Research Document, Government of Canada, Fisheries and Oceans Canada, Nanaimo

Parsons TR, Albright LJ, Parslow J (1980) Is the Strait of Georgia becoming more eutrophic? Can J Fish Aquat Sci 37: 1043-1046

Paul PK, Paul PC, Carmack E, Macdonald RW (1995) The care-takers: the re-emergence of the Saanich Indian map. WÀSNEĆ Nation and Fisheries and Oceans Canada, Institute of Ocean Sciences, Sidney

> Pauly D, Alder J, Bennett E, Christensen V, Tyedmers P, Watson R (2003) The future for fisheries. Science 302: 1359-1361

Pawlowicz R, Riche O, Halverson M (2007) The circulation and residence time of the Strait of Georgia using a simple mixing-box approach. Atmos-Ocean 45:173-193

Perry RI, Schweigert JF (2008) Primary productivity and the carrying capacity for herring in NE Pacific marine ecosystems. Prog Oceanogr 77:241-251

Pitcher TJ (2001) Fisheries managed to rebuild ecosystems? Reconstructing the past to salvage the future. Ecol Appl 11:601-617

Robinson LA, Frid CLJ (2008) Historical marine ecology: examining the role of fisheries in changes in North Sea benthos. Ambio 37:362-371

Ross PS (2006) Fireproof killer whales (Orcinus orca): flameretardant chemicals and the conservation imperative in the charismatic icon of British Columbia, Canada. Can J Fish Aquat Sci 63:224-234

Ross P, De Swart R, Addison R, Van Loveren H, Vos J, Osterhaus A (1996) Contaminant-induced immunotoxicity in harbour seals: Wildlife at risk? Toxicology 112:157-169

Ross PS, Ellis GM, Ikonomou MG, Barrett-Lennard LG, Addison RF (2000) High PCB concentrations in free-ranging Pacific killer whales, Orcinus orca: effects of age, sex and dietary preference. Mar Pollut Bull 40:505-515

Ross PS, Jeffries SJ, Yunker MB, Addison RF, Ikonomou MG, Calambokidis J (2004) Harbour seals (Phoca vitulina) in British Columbia, Canada, and Washington State, USA, reveal a combination of local and global polychlorinated biphenyl, dioxin and furan signals. Environ Toxicol Chem 23:157-165

Ross PS, Stern GA, Lebeuf M (2007) Trouble at the top of the food chain: environmental contaminants and health risks in marine mammals - a white paper on research priorities for Fisheries and Oceans Canada. Can Tech Rep Fish Aquat Sci 2734

Ross PS, Couillard CM, Ikonomou MG, Johannessen SC, Lebeuf M, Macdonald RW, Tomy G (2009) Large and growing environmental reservoirs of deca-BDE present an emerging health risk for fish and marine mammals. Mar Pollut Bull 58:7-10

Saunders MW, McFarlane GA (1999) Pacific hake-Strait of Georgia Assessment for 1999 and recommended yield options for 2000. Report No. 99/2000, Government of
Canada, Fisheries and Oceans Canada, Nanaimo

Schweigert J, Haist V (2007) Stock assessment for British Columbia herring in 2006 and forecasts for the potential catch in 2007. Report No. 2007/002, Government of Canada, Fisheries and Oceans Canada, Nanaimo

> Shang DY, Macdonald RW, Ikonomou MG (1999) Persistence of nonylphenol ethoxylate surfactants and their primary degradation products in sediments from near a municipal outfall in the Strait of Georgia, British Columbia, Canada. Environ Sci Technol 33:1366-1372

Shaw J, Taylor RB, Forbes DL, Ruz MH, Solomon S (1998) Sensitivity of the coasts of Canada to sea-level rise. Report No. 505, Natural Resources Canada, Dartmouth

> Sherry TW, Holmes RT (1996) Winter habitat quality, population limitation, and conservation of neotropical-nearctic migrant birds. Ecology 77:36-48

Shirayama Y, Thornton H (2005) Effect of increased atmospheric $\mathrm{CO}_{2}$ on shallow water marine benthos. J Geophys Res 110:C09S08 doi:10.1029/2004JC002618

Simpson K, Dobson D, Semple R, Lehmann SB, Matthews I (2001) Status in 2000 of Coho stocks adjacent to the Strait of Georgia. Report No. 2001/144, Government of Canada, Fisheries and Oceans Canada, Nanaimo

Slaney T, Hyatt KD, Northcote TG, Fielden RJ (1996) Status of anadromous salmon and trout in British Columbia and Yukon. Fisheries 21:20-35

St. John M, Macdonald JS, Harrison PJ, Beamish RJ, Choromanski E (1992) The Fraser River plume: some preliminary observations on the distribution of juvenile salmon, herring and their prey. Fish Oceanogr 1:153-162

St. John MA, Marinone SG, Stronach J, Harrison PJ, Fyfe J, Beamish RJ (1993) A horizontally resolving physical-biological model of nitrate concentration and primary productivity in the Strait of Georgia. Can J Fish Aquat Sci 50: $1456-1466$

Stewart C, Thompson JAJ (1994) Extensive butyltin contamination in southwestern coastal British Columbia. Mar Pollut Bull 28:601-606

Stockholm Convention (2001) Stockholm Convention on persistent organic pollutants (POPs), adopted 22 May 2001. Available at: http://chm.pops.int/ (accessed October 31, 2008)

Summers RW, Strann KB, Rae R, Heggas J (1990) Wintering purple sandpipers (Calidris maritima) in Troms County, northern Norway. Ornis Scand 21:248-254

Thomson RE (1981) Oceanography of the British Columbia coast. Can Spec Publ Fish Aquat Sci 56

Thurman EM (1985) Organic geochemistry of natural waters Martinus Nijhoff, Dordrecht

Tunnicliffe V, O'Connell JM, McQuoid MR (2001) A Holocene record of marine fish remains from the northeastern Pacific. Mar Geol 174:197-210

Vaquer-Sunyer R, Duarte CM (2008) Thresholds of hypoxia for marine biodiversity. Proc Natl Acad Sci USA 105: 15452-15457

Waldichuk M (1957) Physical oceanography of the Strait of Georgia. J Fish Res Board Can 14:321-486

Wallace SS (1998) Changes in human exploitation of marine resources in British Columbia (pre-contact to present day). In: Pauly D, Pitcher T, Preikshot D, Hearne J (eds) Back to the future: reconstructing the Strait of Georgia ecosystem. Fisheries Centre Research Reports, University of British Columbia, Vancouver, 6(5):56-62

Whitfield PH, Wang JW, Cannon AJ (2003) Modelling future streamflow extremes - floods and low flows in Georgia Basin, British Columbia. Can Water Resour J 28:633-656 Whitney FA, Freeland HJ, Robert M (2007) Persistently de- 
clining oxygen levels in the interior waters of the eastern subarctic Pacific. Prog Oceanogr 75:179-199

Widdicombe S, Spicer JI (2008) Predicting the impact of ocean acidification on benthic biodiversity: What can animal physiology tell us? J Exp Mar Biol Ecol 366:187-197

Willey JD, Kieber RJ, Eyman MS, Avery GB (2000) Rainwater dissolved organic carbon: concentrations and global flux. Global Biogeochem Cycles 14:139-148

> Wootton JT, Pfister CA, Forester JD (2008) Dynamic patterns and ecological impacts of declining ocean $\mathrm{pH}$ in a highresolution multi-year dataset. Proc Natl Acad Sci USA 105: 18848-18853

Editorial responsibility: Nils Chr. Stenseth, Oslo, Norway
Yin K, Harrison PJ, Pond S, Beamish RJ (1995) Entrainment of nitrate in the Fraser River Estuary and its biological implications. II. Effects of spring vs. neap tides and river discharge. Estuar Coast Shelf Sci 40:529-544

Yin K, Harrison PJ, Goldblatt RH, St. John MA, Beamish RJ (1997) Factors controlling the timing of the spring bloom in the Strait of Georgia estuary, British Columbia, Canada. Can J Fish Aquat Sci 54:1985-1995

Yunker MB, Macdonald RW, Goyette D, Paton D, Fowler BR, Sullivan D, Boyd J (1999) Natural and anthropogenic inputs of hydrocarbons to the Strait of Georgia. Sci Total Environ 225:181-209

Submitted: January 2, 2009; Accepted: June 9, 2009

Proofs received from author(s): August 20, 2009 